\title{
EFFECTS OF MANAGEMENT PRACTICES ON WETLAND BIRDS:
}

\section{VIRGINIA RAIL}

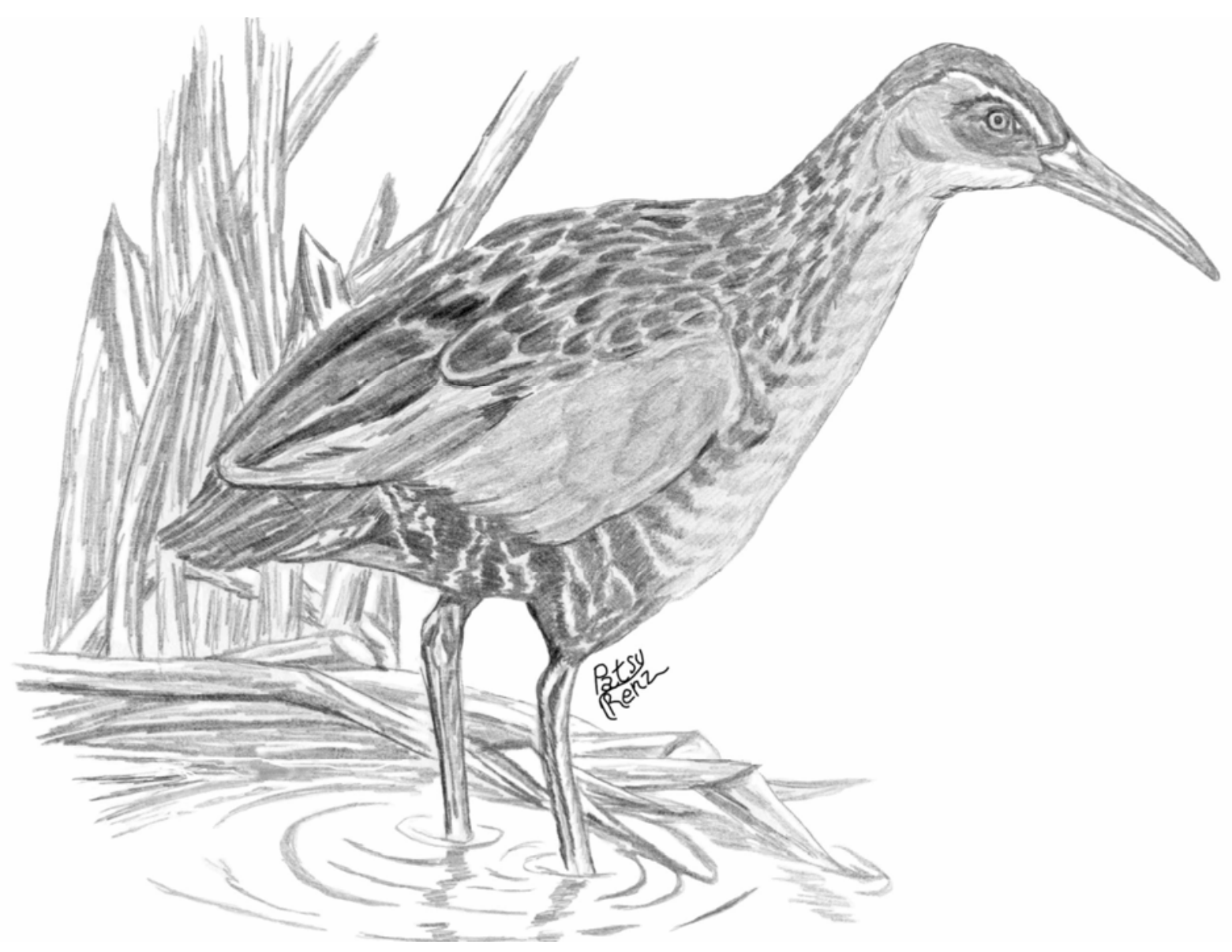

Grasslands Ecosystem Initiative

Northern Prairie Wildlife Research Center

U.S. Geological Survey

Jamestown, North Dakota 58401 
This report is one in a series of literature syntheses on North American wetland birds. The need for these reports was identified by the Prairie Pothole Joint Venture (PPJV), a part of the North American Waterfowl Management Plan. The PPJV adopted a goal to stabilize or increase populations of declining grasslandand wetland-associated wildlife species in the Prairie Pothole Region. To further that objective, it is essential to understand the habitat needs of birds other than waterfowl, and how management practices affect their habitats. The focus of these reports is on management of breeding habitat, particularly in the northern Great Plains.

Suggested citation:

Zimmerman, A. L., J. A. Dechant, B. E. Jamison, D. H. Johnson, C. M. Goldade, J. O. Church, and B. R. Euliss. 2002. Effects of management practices on wetland birds: Virginia Rail. Northern Prairie Wildlife Research Center, Jamestown, ND. 31 pages.

Species for which syntheses are available or are in preparation:

Eared Grebe

American Bittern

Virginia Rail

Sora

Yellow Rail

American Avocet

Willet

Long-billed Curlew
Marbled Godwit

Wilson's Phalarope

Black Tern

Marsh Wren

Sedge Wren

Le Conte's Sparrow

Nelson's Sharp-tailed Sparrow 
EFFECTS OF MANAGEMENT PRACTICES ON WETLAND BIRDS:

VIRGINIA RAIL

Amy L. Zimmerman, Jill A. Dechant, Brent E. Jamison, Douglas H. Johnson, Christopher M. Goldade, James O. Church, and Betty R. Euliss

Series Coordinator: Douglas H. Johnson

Series Assistant Coordinator: Jill A. Dechant

Reviewer: Courtney J. Conway

Range Map: Jeff A. Price

Cover Art: Patsy Renz

Major Funding: Prairie Pothole Joint Venture

U.S. Fish and Wildlife Service

U.S. Geological Survey

November 2002 


\section{ORGANIZATION AND FEATURES OF THIS SPECIES ACCOUNT}

Information on the habitat requirements and effects of habitat management on wetland birds were summarized from information in more than 500 published and unpublished papers. A range map is provided to indicate the relative densities of the species in North America, based on Breeding Bird Survey (BBS) data. Although the BBS may not capture the presence of elusive waterbird species, the BBS is a standardized survey and the range maps, in many cases, represent the most consistent information available on species' distributions. Although birds frequently are observed outside the breeding range indicated, the maps are intended to show areas where managers might concentrate their attention. It may be ineffectual to manage habitat at a site for a species that rarely occurs in an area. The species account begins with a brief capsule statement, which provides the fundamental components or keys to management for the species. A section on breeding range outlines the current breeding distribution of the species in North America, including areas that could not be mapped using BBS data. The suitable habitat section describes the breeding habitat and occasionally microhabitat characteristics of the species, especially those habitats that occur in the Great Plains. Details on habitat and microhabitat requirements often provide clues to how a species will respond to a particular management practice. A table near the end of the account complements the section on suitable habitat, and lists the specific habitat characteristics for the species by individual studies. The area requirements section provides details on territory and home range sizes, minimum area requirements, and the effects of patch size, edges, and other landscape and habitat features on abundance and productivity. It may be futile to manage a small block of suitable habitat for a species that has minimum area requirements that are larger than the area being managed. The section on brood parasitism summarizes information on intra- and interspecific parasitism, host responses to parasitism, and factors that influence parasitism, such as nest concealment and host density. The impact of management depends, in part, upon a species' nesting phenology and biology. The section on breeding-season phenology and site fidelity includes details on spring arrival and fall departure for migratory populations in the Great Plains, peak breeding periods, the tendency to renest after nest failure or success, and the propensity to return to a previous breeding site. The duration and timing of breeding varies among regions and years. Species' response to management summarizes the current knowledge and major findings in the literature on the effects of different management practices on the species. The section on management recommendations complements the previous section and summarizes recommendations for habitat management provided in the literature. The literature cited contains references to published and unpublished literature on the management effects and habitat requirements of the species. This section is not meant to be a complete bibliography; a searchable, annotated bibliography of published and unpublished papers dealing with habitat needs of wetland birds and their responses to habitat management is posted at the Web site mentioned below.

This report has been downloaded from the Northern Prairie Wildlife Research Center WorldWide Web site, www.npwrc.usgs.gov/resource/literatr/grasbird/grasbird.htm. Please direct comments and suggestions to Douglas H. Johnson, Northern Prairie Wildlife Research Center, U.S. Geological Survey, 8711 37th Street SE, Jamestown, North Dakota 58401; telephone: 701253-5539; fax: 701-253-5553; e-mail: Douglas_H_Johnson@usgs.gov. 


\section{Virginia Rail}

(Rallus limicola)

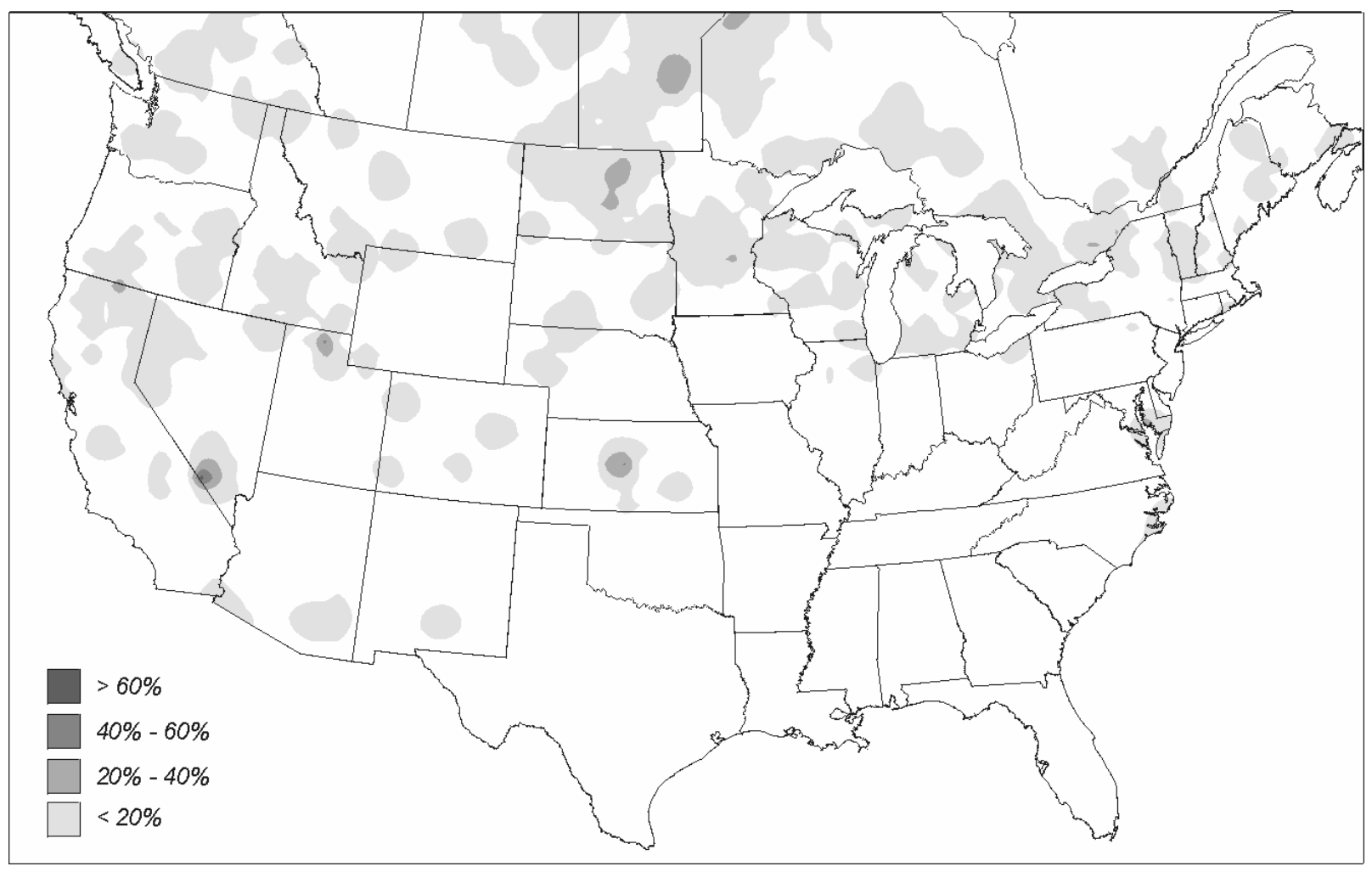

Figure. Probability of occurrence (number of years detected/number of years route was run) of Virginia Rails in the United States and southern Canada, based on Breeding Bird Survey data, 1973-1996. Map courtesy of Jeff T. Price.

Key to management is providing seasonal and semipermanent wetlands with water depths ranging from 0 to $15 \mathrm{~cm}$, with high invertebrate abundance, and with moderate proportions (30-70\%) of emergent vegetation interspersed with open water, mudflat, and to a lesser extent, floating residual vegetation. The following account does not address harvest, but instead focuses on habitat management.

\section{Breeding Range:}

Virginia Rails breed in southcentral British Columbia, southcentral Alberta, southern Saskatchewan, Manitoba, Ontario, and Quebec, throughout New Brunswick, Nova Scotia, and Maine, south to central California, northern Arizona, northern New Mexico, central Kansas, northern Iowa, and east to New Jersey (National Geographic Society 1999). (See figure for the probability of occurrence of Virginia Rails in the United States and southern Canada, based on Breeding Bird Survey data.)

\section{Suitable habitat:}

Virginia Rails breed in fresh and sometimes brackish seasonal and semipermanent wetlands with water depths ranging from 0 to $15 \mathrm{~cm}$, high invertebrate abundance, and moderate (30-70\%) proportions of emergent vegetation interspersed with open water, mudflat, and to a 
lesser extent, floating residual vegetation (Beattie 1899; Billard 1948; Bent 1963; Stewart and Kantrud 1965; Baird 1974; Stewart 1975; Tacha 1975; Griese 1977; Krapu and Green 1978; Griese et al. 1980; Faanes 1981; Rundle and Fredrickson 1981; Kantrud and Stewart 1984; Sayre and Rundle 1984; Zimmerman 1984; Fredrickson and Reid 1986; Manci and Rusch 1988, 1989; Conway and Eddleman 1994; Crowley 1994; Conway 1995; Fairbairn and Dinsmore 2001a,b; Prescott et al. 2001). Virginia Rails also breed in wet meadows, fens, permanent wetlands, restored wetlands, freshwater impoundments, salt marshes, and in emergent vegetation along the banks of streams, rivers, or lakes (Griffing 1881; Beattie 1899; Batts 1958; Boyer and Devitt 1961; Post and Enders 1970; Griese 1977; Zimmerman 1977; Griese et al. 1980; Faanes 1981, 1982; Kantrud and Stewart 1984; Svedarsky 1992; VanRees-Siewert 1993; Hartman 1994; Schrieber 1994; Conway 1995; VanRees-Siewert and Dinsmore 1996; Schuster 1998; Whitt et al. 1999; Dault 2001; Fairbairn and Dinsmore 2001a; Prescott et al. 2001). Although water depths $\leq 15 \mathrm{~cm}$ are preferred, water $>15 \mathrm{~cm}$ in depth will be more readily used if floating residual vegetation is present to allow rails to walk rather than to swim (Sayre and Rundle 1984, Johnson and Dinsmore 1985, Conway and Eddleman 1994, Conway 1995). Virginia Rails may be found in areas with water depths up to $71 \mathrm{~cm}$ (Horak 1964).

The presence of Virginia Rails in wetlands is closely tied to the presence of emergent vegetation and rails occur in a variety of emergent vegetation types (Kaufmann 1971; Stewart 1975; Zimmerman 1977; Faanes 1982; Johnson and Dinsmore 1986; Manci and Rusch 1988, 1989; Conway 1995; Faanes and Lingle 1995; Graetz et al. 1997; Naugle 1997; Ribic 1999; Dault 2001; Fairbairn and Dinsmore 2001a,b; Naugle et al. 2001). However, areas with extremely dense emergent vegetation generally are avoided because dense vegetation hinders movement (Johnson 1984, Conway and Eddleman 1994, Conway 1995). In Iowa, the presence of Virginia Rails was positively related to habitat diversity (measure of the evenness of the distribution of the vegetation zones [e.g., wet-meadow zone, shallow-marsh zone, deep-marsh zone, permanent-open-water zone; Stewart and Kantrud 1971]) and negatively related to percent open water (Fairbairn and Dinsmore 2001a). Virginia Rail density was positively related to the small areas of open water interspersed within the emergent vegetation zone of wetlands, with the area of wet-meadow vegetation cover, and with percent emergent vegetation cover (Fairbairn and Dinsmore 2001a,b). In another Iowa study, the presence of Virginia Rails was positively related to percent emergent vegetation cover in wetlands (Dault 2001). In South Dakota, presence of Virginia Rails in seasonal and semipermanent wetlands was positively related to the percent of wetland area that was vegetated and to the abundance of thick-stemmed plants (e.g., cattail [Typha spp.]) (Naugle 1997, Naugle et al. 2001). In Massachusetts, presence of Virginia Rails was positively associated with the area of cattail within wetlands and with the area of fineleaved emergents (e.g., sedges [Carex spp.] and grasses [scientific names not given]) within wetlands (Crowley 1994).

Virginia Rails nest among various plant species, including sedge, cattail, bulrush (Schoenoplectus spp.), rush (Juncus spp.), cordgrass (Spartina spp.), reed canary grass (Phalaris arundinacea), bur-reed (Sparganium eurycarpum), common reed (Phragmites australis), bittersweet (Celastrus spp.), sprangletop (Scolochloa festucacea), hairy whitetop (Cardaria pubescens), bluejoint (Calamagrostis canadensis), swamp loosestrife (Decodon verticillatis), and sweetflag (Acorus americanus) (Shaw 1887; Hathorn 1902; Burtch 1917; Mousley 1931, 1937, 1940; Allen 1934; Walkinshaw 1937; Wood 1937; Randall 1946; Provost 1947; Billard 
1948; Berger 1951; Pospichal 1952; Tanner 1953; Tanner and Hendrickson 1954; Lindmeier 1960; Lowther 1961; Bent 1963; Horak 1964; Kaufmann 1971, 1989; Stabler and Kitzmiller 1971; Andrews 1973; Baird 1974; Glahn 1974; Stewart 1975; Tacha 1975; Griese 1977; Zimmerman 1977; Beule 1979; Johnsgard 1979, 1980; Griese et al. 1980; Kantrud and Higgins 1992; Conway and Eddleman 1994; Conway 1995). Virginia Rail nests are generally placed 3$30 \mathrm{~cm}$ above water that is 5-33 cm in depth; nests occasionally may be placed on damp or dry ground (Mousley 1937; Walkinshaw 1937; Wood 1937; Provost 1947; Billard 1948; Berger 1951; Pospichal 1952; Bent 1963; Andrews 1973; Baird 1974; Tacha 1975; Stewart 1975; Zimmerman 1977; Johnsgard 1979, 1980; Svedarsky 1992; Conway 1995). Virginia Rails avoid nesting near open water (Provost 1947, Andrews 1973), but will nest within $15 \mathrm{~m}$ of edges between vegetation types (Pospichal 1952, Glahn 1974, Conway 1995). Vegetation height at nest sites varies widely and is not a critical component of Virginia Rail habitat as long as some overhead cover is available (Johnson 1984, Johnson and Dinsmore 1986, Conway and Eddleman 1994, Conway 1995). Virginia Rails typically create a canopy of emergent vegetation over the nest, as well as ramps of vegetation that lead up to the nest from the water (Gillette 1897, Beattie 1899, Allen 1934, Walkinshaw 1937, Billard 1948, Tanner 1953, Stewart 1975). Nests occasionally are found in uplands, several meters away from wetland edges (Stewart 1975, Fuller et al. 1979). Inactive, multiple nests that serve as resting and feeding platforms may be constructed (Pospichal 1952, Pospichal and Marshall 1954, Conway 1995). Virginia Rails often nest in in the same wetlands as Soras (Porzana carolina) and Least Bitterns (Ixobrychus exilis) (Billard 1948, Berger 1951, Pospichal 1952, Tanner and Hendrickson 1954, Glahn 1974, Johnson 1984). A table near the end of the account lists the specific habitat characteristics for Virginia Rails by study.

Postbreeding and migratory movements:

Virginia Rails often disperse from breeding wetlands in late summer (July and August) to either forage in adjacent upland habitat or to gather on large wetlands prior to fall migration (Pospichal 1952, Pospichal and Marshall 1954, Johnson 1984, Johnson and Dinsmore 1985). Concentrations of birds on large wetlands prior to fall migration may be related to decreasing water levels in smaller breeding wetlands (Conway 1995). In Iowa, postbreeding Virginia Rails were found from 1 to $6 \mathrm{~km}$ from the breeding wetland (Johnson 1984).

Migrating Virginia Rails may use shallowly flooded moist-soil impoundments or oxbow lakes (Rundle and Fredrickson 1981, Sayre and Rundle 1984, Vogel 1999). In Missouri, migrating Virginia Rails were most common in a moist-soil impoundment that had water depths ranging from 5 to $15 \mathrm{~cm}$ deep and that contained mixed stands of beggartick (Bidens spp.), lateflowering thoroughwort (Eupatorium serotinum), and barnyard grass (Echinochloa muricata and E. crusgalli) (Rundle and Fredrickson 1981). Rails most frequently occupied areas with mean water depths $\leq 5 \mathrm{~cm}$ and with emergent vegetation that was tall $(>30 \mathrm{~cm})$, dense $(>30$ contacts using the point-intercept method), and dominated by beggartick, broomsedge (Andropogon virginicus), sedges (Carex spp. and Cyperus spp.), rushes, lateflowering thoroughwort, and annual grasses such as panicgrass (Panicum sp.) and crabgrass (Digitaria sp. and Echinochloa spp.) (Sayre and Rundle 1984). Virginia Rails using oxbow lakes along the Missouri River preferred water depths ranging from 0 to $8 \mathrm{~cm}$ and areas dominated by river bulrush (Schoenoplectus fluviatilis), knotweed (Polygonum spp.), and common buttonbush 
(Cephalanthus occidentalis) (Vogel 1999).

Area requirements:

Virginia Rails occupy wetlands that range in size from small ( $<1 \mathrm{ha})$ to large ( $>20 \mathrm{ha}$ ) (Zimmerman 1977, Krapu and Green 1978, Brown and Dinsmore 1986, Gibbs et al. 1991, Daub 1993). In Iowa, frequency of occurrence of Virginia Rails was 92\% in wetlands 1-4.9 ha, 5-10.9 ha, and 11-20 ha in size, 83\% in wetlands $>20$ ha, and $42 \%$ in wetlands $<1$ ha in size (Brown and Dinsmore 1986). The home ranges of nine Virginia Rails during the brood-rearing season in Iowa averaged 0.18 ha; five individual male ranges averaged 0.16 ha and four individual female ranges averaged 0.22 ha (Johnson and Dinsmore 1985). In Arizona, Conway (1990) estimated mean daily movements and mean home range sizes for adult Virginia Rails in the early breeding season (March-April) and late breeding season (May-July). In the early breeding season, mean daily movement of eight rails was $66.8 \mathrm{~m}$, and mean home range size for seven rails was 1.64 ha. In the late breeding season, mean daily movement of 12 rails was $68.8 \mathrm{~m}$, and mean home range size for 10 rails was 1.56 ha.

\section{Brood parasitism:}

The Virginia Rail is considered an accidental host choice for the Brown-headed Cowbird (Molothrus ater). Only one instance of brood parasitism has been reported; one Virginia Rail nest containing eight rail eggs and one Brown-headed Cowbird egg was found in Ontario (Friedmann et al. 1977). Soras may lay eggs in Virginia Rail nests and vice versa (Miller 1928, Allen 1934, Tanner 1953, Tanner and Hendrickson 1954, Conway 1995).

Intraspecific brood parasitism in Virginia Rails also may occur (Tanner and Hendrickson 1954).

\section{Breeding-season phenology and site fidelity:}

Virginia Rails arrive on the breeding grounds from mid-March to late May and depart from mid-August to early November (Gillette 1897; Hathorn 1902; Hersey 1910; Cooke 1914; Allen 1934; Walkinshaw 1937; Billard 1948; Pospichal 1952; Pospichal and Marshall 1954; Tanner 1953; Tanner and Hendrickson 1954; Lindmeier 1960; Bent 1963; Parmelee et al. 1970; Kaufmann 1971, 1989; Andrews 1973; Baird 1974; Tacha 1975; Griese 1977; Griese et al. 1980; Faanes 1981; Janssen 1987; Manci and Rusch 1988; Conway 1995; Kent and Dinsmore 1996). The breeding season extends from mid-May to mid-August, and nest initiation peaks from midMay through mid-June (Billard 1948, Stewart 1975, Kent and Dinsmore 1996). Virginia Rails may renest after the failure of an initial nest (Allen 1934, Walkinshaw 1937, Billard 1948, Pospichal 1952, Tanner and Hendrickson 1954, Lindmeier 1960, Krapu and Green 1978). Although data are limited, Virginia Rails generally are considered single-brooded (Conway 1995). Little is known about breeding-site fidelity. In Iowa, Tanner and Hendrickson (1954) banded Virginia Rails as juveniles or flightless adults, but none were recaptured in subsequent years. In Arizona, banded adults occupied the same breeding area for three consecutive years (Courtney J. Conway, U.S. Geological Survey, Arizona Cooperative Fish and Wildlife Research Unit, Tucson, Arizona, pers. comm.). 
Species' response to management:

Virginia Rails favor wetlands with shallow water and with moderate ratios of emergent vegetation to open water, mudflat, and floating residual vegetation (Weller and Fredrickson 1973; Fredrickson and Reid 1986; Conway and Eddleman 1994; Fairbairn and Dinsmore $2001 a, b)$. Favorable water levels and favorable proportions of vegetation cover and open water can be maintained by artificially manipulating water levels of wetlands or wetland complexes through the use of water control structures. In an experimentally manipulated wetland in Iowa, the density of Virginia Rails peaked the year of reflooding when the wetland was dominated by sparse and well-dispersed annuals and immature perennials. Rail density declined over the next three years as a dense bed of perennials became established, and then density increased over the next two years as the vegetation-to-water ratio approached 50:50 (Weller and Fredrickson 1973).

Little is known about the effects of burning, mowing, or grazing on Virginia Rails. Kantrud and Stewart (1984) suggested that occasional burning or grazing is required to maintain wetland vegetation in the best condition for many avian species, including rail species. When these management practices are conducted in a timely and well-planned manner, they can decrease the extent of monotypic stands of emergent vegetation and create openings in the vegetation, which can potentially increase biological productivity within shallow-water zones. Overgrazing of wetland vegetation by livestock during dry periods, however, may eliminate emergent vegetation needed for breeding (Marshall 1952). Boyer and Devitt (1961) suggested fencing wetlands where appropriate to exclude livestock. In Colorado, irrigation practices that resulted in mid-summer drying of wetlands caused premature concentrations and movements of rails in July and early August (Griese et al. 1980).

Some restored wetlands can provide nesting habitat for Virginia Rails (Svedarsky 1992, VanRees-Siewert 1993, Hartman 1994, VanRees-Siewert and Dinsmore 1996, Schuster 1998, Dault 2001). In Iowa, Virginia Rails nested in one of six 2-yr-old restored wetlands and two of six 4-yr-old restored wetlands and were present on wetlands restored for 1-4 yr; the study did not examine restored wetlands older than 4 yr (VanRees-Siewert 1993, VanRees-Siewert and Dinsmore 1996). In another Iowa study, Virginia Rails nested on six of eight natural wetlands, one of eight 4- to 6-yr-old restored wetlands, and three of eight 8- to 12-yr-old restored wetlands; the study did not examine restored wetlands older than 12 yr (Dault 2001). Virginia Rails were most likely to be detected in natural wetlands, followed by 8-12-yr-old restored wetlands and

4- to 6-yr-old restored wetlands. Presence of Virginia Rails was positively related to the number and total area of wetlands within $1500 \mathrm{~m}$ of the surveyed wetland, indicating that wetland restorations near or within wetland complexes might attract Virginia Rails (Dault 2001). Schuster (1998) found similar numbers of Virginia Rail nests in natural and restored wetlands in Iowa. In Indiana, Virginia Rails nested in two of 26 restored wetlands, whereas no nests were found in seven natural wetlands (Hartman 1994). Brady (1983) found that Virginia Rail densities were higher in natural semipermanent wetlands than in dug brood complexes (modified wetlands comprising a system of channels, ponds, and human-created islands to provide deep, open water and upland nesting areas for waterfowl), although they were relatively common in both habitats.

The effects of most pesticides and contaminants on rails is poorly studied. Thirteen months after $0.22 \mathrm{~kg} / \mathrm{ha}$ DDT was experimentally applied to a 1.62-ha wetland, DDT residues from the fat of three Virginia Rails were 7.6 parts per million (ppm), 7.5 ppm, and $19.0 \mathrm{ppm}$, 
respectively (Meeks 1968). The study specifically examined the process of bioaccumulation and did not present information on toxicity levels for Virginia Rails. In Georgia, one Virginia Rail analyzed for mercury bioaccumulation contained $0.4 \mathrm{ppm}$ mercury in its liver, which was below the allowable limit (0.5 ppm) for human consumption (Odom 1975). However, 69\% of 13 Sora livers analyzed had mercury levels $>0.50 \mathrm{ppm}$. Application of mosquito (Culicidae) control chemicals reduces the availability of potential invertebrate prey items for rails (Hanowski et al. 1997).

Virginia Rails commonly collide with utility wires or towers when flying low at night during migration and are susceptible to collisions with automobiles (Shaw 1887, Tordoff and Mengel 1956, Pulich 1961, Avery and Clement 1972, Crawford 1974, Odom 1975, Conway 1995). One adult female Virginia Rail was found impaled on a barbed wire fence in Iowa (Tanner 1953).

Effects of purple loosestrife (Lythrum salicaria) invasion of wetlands on breeding Virginia Rails is unknown. In Michigan, Whitt et al. (1999) found a Virginia Rail nest in purple loosestrife habitat. Virginia Rails may be sensitive to human disturbance. In Massachusetts, Virginia Rail presence was negatively related to the number of human habitations within $500 \mathrm{~m}$ of wetland edges (Crowley 1994).

\section{Management Recommendations:}

The management recommendations that follow are based on the species' habitat requirements and may apply to the community of wetland bird species as a whole. Wetland loss and degradation should be avoided (Zimmerman 1977, Brown and Dinsmore 1986, Daub 1993, VanRees-Siewert 1993, Conway and Eddleman 1994, Faanes and Lingle 1995, Naugle et al. 2001). The long-term protection of wetlands can be achieved through conservation easements and purchases of wetland basins (Holliman 1977, VanRees-Siewert 1993, Conway and Eddleman 1994, VanRees-Siewert and Dinsmore 1996, Weller 1999, Dault 2001). The ideal management strategy for waterbirds is to maintain wetland complexes and large wetlands or lakes (Kantrud and Stewart 1984, Brown and Dinsmore 1986, Fredrickson and Reid 1986, Daub 1993, Conway and Eddleman 1994, Weller 1999, Dault 2001, Naugle et al. 2001). Because of variation in water levels over seasons or years, wetland complexes are more likely to have at least some wetlands in a water and plant regime favorable to a particular species, thus ensuring diverse species' representation in a geographical area (Pospichal and Marshall 1954, Weller 1999). Dynamic and ephemeral habitats, such as mudflats, sandbars, and meadows subject to flooding, should also be protected, because these are important aspects to Virginia Rail breeding and foraging habitat (Conway and Eddleman 1994, Conway 1995, Weller 1999).

Where water-control structures allow for manipulation of water levels within wetlands and impoundments, conduct gradual drawdowns that encourage the growth of diverse stands of robust (e.g., cattail, river bulrush), moderately robust (e.g., hardstem bulrush, bur-reed), and fine (sedges) emergent vegetation as well as seed-producing annuals (e.g., knotweed [Polygonum]) (Johnson and Dinsmore 1986). Discourage the development of Stewart and Kantrud (1971) cover types 3 (centrally located expanse of open water surrounded by a peripheral band of emergent vegetation), and 4 (largely devoid of any kind of emergent cover); the former isolates 
potential breeding habitat from upland and wetland edge seed-producing plants, whereas the latter provides little suitable emergent habitat (Johnson 1984, Johhnson and Dinsmore 1986). Generally, avian productivity and diversity are maximized in hemi-marsh situations (50:50 vegetation cover to water ratio), and these habitats are adequate for breeding rails. Conduct complete drawdowns during the fall and winter, or prior to 15 April, and then reflood so that some water is available between 15 April and 1 August to provide migrant, breeding, and broodrearing habitat for rails (Andrews 1973, Griese 1977, Rundle and Fredrickson 1981, Johnson 1984, Johnson and Dinsmore 1986). If possible, divide a wetland into several independently controlled units to allow for biennial drawdowns (Andrews 1973). This practice allows total drawdowns of some wetlands and the maintenance of standing water in others. Fall flooding of robust emergents and perennials attracts migrating rails and also decreases the vigor of perennial species so that seed-producing annuals can become established in the spring to provide foraging habitat (Fredrickson and Reid 1986). Foraging habitat also may be created by shallowly flooding areas of heterogeneous topography or by conducting partial drawdowns of more homogeneous human-created wetlands; both of these techniques concentrate invertebrate prey (Fredrickson and Reid 1986, Conway and Eddleman 1994, Conway 1995).

Prevent extensive lodging of emergent vegetation stands with residual stems because this can impede rail movement (Johnson 1984). Wetlands with dense stands of emergent vegetation that impede rail movement should be burned, disced, mowed, or plowed to set back succession and, if within a managed impoundment, should be reflooded to stimulate production of invertebrates (Johnson 1984, Kantrud and Stewart 1984, Conway and Eddleman 1994). To reduce woody invasion and stimulate the growth of robust annuals used by migrating rails, disc dry wetlands and then reflood with shallow ( $\leq 15 \mathrm{~cm}$ deep) water (Fredrickson and Reid 1986, Conway and Eddleman 1994).

Some restored wetlands can provide important breeding habitat for Virginia Rails (Svedarsky 1992, VanRees-Siewert 1993, Hartman 1994, VanRees-Siewert and Dinsmore 1996, Schuster 1998, Dault 2001). Focus restoration efforts on providing a diverse vegetative community that closely resembles natural wetlands (Dault 2001). To promote quick response of wetland vegetation, restore recently ( $<30 \mathrm{yr}$ ago) drained wetlands or wetlands that were not effectively drained, such as those typically used for pasture or hayfields for which there is less incentive to completely drain the area (Hemesath 1991, Hemesath and Dinsmore 1993). Active planting of wet-meadow species in restoration projects may be needed to attract wet-meadow nesting species such as rails and bitterns (VanRees-Siewert 1993, VanRees-Siewert and Dinsmore 1996, Dault 2001). Revegetation of restored wetlands varies with duration of drainage, past herbicide use and cropping system, effectiveness of drainage, and isolation; consider these factors when selecting restoration sites (VanRees-Siewert 1993, VanRees-Siewert and Dinsmore 1996). Dault (2001) suggested that $>12$ yr was needed to attain the full range of wetland bird species present on natural wetlands because species richness remained higher on natural than on restored wetlands $12 \mathrm{yr}$ post restoration in Iowa. When feasible, restore wetlands within wetland complexes or those that are surrounded by a high density of wetlands in the landscape (VanRees-Siewert 1993, VanRees-Siewert and Dinsmore 1996, Dault 2001, Fairbairn and Dinsmore 2001a). Restoring groups of wetlands of various types and sizes will provide habitat regardless of water conditions in a given year (Hemesath 1991, Hemesath and Dinsmore 1993, Dault 2001, Fairbairn and Dinsmore 2001a). 
In general, avian mortality due to power line collisions can be reduced by placing utility lines several kilometers away from wetlands, waterfowl concentration areas, flyways, roosting areas, feeding areas, low passes, breeding areas, and especially paths between feeding and roosting or nesting areas (Thompson 1978, Malcolm 1982). Mortality due to fences can be reduced by reviewing fence construction plans and modifying plans for proposed management projects (i.e., replacing or removing dangerous fences) (Allen and Ramirez 1990). Fences placed through wetlands should be replaced or marked to make them conspicuous and to decrease likelihood of bird/fence collisions. 
Table. Virginia Rail habitat characteristics.

\begin{tabular}{|c|c|c|c|}
\hline Author(s) & Location & Habitats Studied & Species-specific Habitat Characteristics \\
\hline Allen 1934 & $\begin{array}{l}\text { Northern } \\
\text { United States } \\
\text { (exact location } \\
\text { not given) }\end{array}$ & River, wetland & $\begin{array}{l}\text { Nested in rushes (Juncus spp.), sedges (Carex spp.), and } \\
\text { cattails (Typha spp.); protective cover was provided by } \\
\text { vegetation that the rails bent over the nest }\end{array}$ \\
\hline Andrews 1973 & Ohio & Wetland & $\begin{array}{l}\text { Nested in a combination of bur-reed (Sparganium } \\
\text { eurycarpum) and bittersweet (Celastrus), and in bluejoint } \\
\text { (Calamagrostis canadensis); nesting material was } \\
\text { bluejoint and bur-reed; water depths at two nests were } 0 \\
\text { cm (damp ground) and } 6.4 \mathrm{~cm} \text {; did not nest near open } \\
\text { water; also were observed in cattail, crimsoneyed } \\
\text { rosemallow (Hibiscus palustris), and bulrush } \\
\text { (Schoenoplectus spp.) }\end{array}$ \\
\hline Baird 1974 & Kansas & Impoundment & $\begin{array}{l}\text { Observed most frequently in cattail ( } 43 \% \text { of } 145 \\
\text { observations) and cattail/softstem bulrush } \\
\text { (Schoenoplectus tabernaemontani) ( } 29 \% \text { ); remaining } \\
\text { observations ( } 28 \% \text { ) were in prairie cordgrass (Spartina } \\
\text { pectinata), alkali bulrush (Scirpus maritimus), inland } \\
\text { saltgrass (Distichlis spicata), or combinations of these } \\
\text { plant species; rails were most commonly observed in } \\
\text { water } 10-15 \mathrm{~cm} \text { deep ( } 42 \% \text { of } 145 \text { observations) followed } \\
\text { by } 5-8 \mathrm{~cm}(29 \%),>15 \mathrm{~cm} \text { ( } 15 \%), 0-2.54 \mathrm{~cm}(12 \%) \text {, and } \\
\text { dry land ( } 2 \%) \text {; the one nest found was located in prairie } \\
\text { cordgrass, } 25 \mathrm{~cm} \text { above water that was } 5 \mathrm{~cm} \text { deep }\end{array}$ \\
\hline Batts 1958 & Michigan & Riparian & $\begin{array}{l}\text { Nested among grass (species not given) clumps at the } \\
\text { edge of a group of cattails growing along the shore of the } \\
\text { Huron River }\end{array}$ \\
\hline
\end{tabular}




\begin{tabular}{|c|c|c|c|}
\hline Beattie 1899 & Ontario & Riparian & $\begin{array}{l}\text { Nested along the bank of a river in a "clump of weeds" } \\
\text { over 15-cm-deep water; nests were concealed using stems } \\
\text { of emergent vegetation that were bent over the nest }\end{array}$ \\
\hline Bent 1963 & Range-wide & Wetland & $\begin{array}{l}\text { Nested in freshwater wetlands; nests were located in } \\
\text { cattail over standing water and were sometimes located } \\
\text { on the ground at the edge of the wetland; one nest was } \\
\text { located } 30 \mathrm{~cm} \text { above water that was } 15 \mathrm{~cm} \text { deep; other } \\
\text { nests were not described }\end{array}$ \\
\hline Berger 1951 & Michigan & Wetland & $\begin{array}{l}\text { Nested in isolated clumps of sedge or in combinations of } \\
\text { cattail and sedge; nests were elevated } 5-13 \mathrm{~cm} \text { above } \\
\text { water }\end{array}$ \\
\hline Beule 1979 & Wisconsin & Wetland & $\begin{array}{l}\text { Of } 10 \text { nests, three were in cattail, three in sedges, two in } \\
\text { other species of vegetation (not defined), one in bur-reed, } \\
\text { and one in softstem bulrush }\end{array}$ \\
\hline Billard 1948 & Connecticut & Wetland & $\begin{array}{l}\text { Of } 24 \text { nests, nine nests were on hummocks of upright } \\
\text { sedge (Carex stricta) or upright sedge and cattail, six } \\
\text { were in sedges and cattail, six were in reed canary grass } \\
\text { (Phalaris arundinacea), two were in sedges, and one was } \\
\text { in cattail; nests were woven baskets of cattail, grasses } \\
\text { (scientific name not given), upright sedge, beaked sedge } \\
\text { (Carex rostrata), or shallow sedge (Carex lurida); nests } \\
\text { commonly had ramps of emergent vegetation from the } \\
\text { water to the nest rim; ramps were typically } 5 \text { cm wide and } \\
30 \text { cm long; a canopy of overhead vegetation was usually } \\
\text { created over the nest; mean height from the water's } \\
\text { surface to the nest rim ranged from } 13 \text { to } 25 \text { cm and } \\
\text { averaged } 16 \text { cm for } 17 \text { nests; water depth at nest sites } \\
\text { ranged from } 6.6 \text { to } 15 \mathrm{~cm}\end{array}$ \\
\hline
\end{tabular}




\begin{tabular}{|c|c|c|c|}
\hline Brady 1983 & South Dakota & $\begin{array}{l}\text { Wetland, wetland } \\
\text { (modified) }\end{array}$ & $\begin{array}{l}\text { Densities were higher in natural wetlands than in dug } \\
\text { brood complexes (modified wetlands comprising a system } \\
\text { of channels, ponds, and human-created islands to provide } \\
\text { deep, open water and upland nesting areas for waterfowl), } \\
\text { but rails were relatively common in both habitats }\end{array}$ \\
\hline Brown and Dinsmore 1986 & Iowa & Wetland & $\begin{array}{l}\text { Frequency of occurrence was } 92 \% \text { in wetlands } 1-4.9 \text { ha, } \\
5-10.9 \text { ha, and } 11-20 \text { ha in size, } 83 \% \text { in wetlands }>20 \text { ha, } \\
\text { and } 42 \% \text { in wetlands }<1 \text { ha in size }\end{array}$ \\
\hline Burtch 1917 & New York & Wetland & Nested in cattail and in sweetflag (Acorus americanus) \\
\hline Conway 1990 & Arizona & Wetland & $\begin{array}{l}\text { Mean daily movement of eight rails in the early breeding } \\
\text { season (March-April) was } 66.8 \mathrm{~m} \text {; mean home range size } \\
\text { for seven rails was } 1.64 \text { ha. Mean daily movement of } 12 \\
\text { rails in the late breeding season (May-July) was } 68.8 \mathrm{~m} \text {; } \\
\text { mean home range size for } 10 \text { rails was } 1.56 \text { ha }\end{array}$ \\
\hline Conway 1995 & Range-wide & Lake, wetland & $\begin{array}{l}\text { Preferred freshwater wetlands, but also nested in brackish } \\
\text { or salt marshes; commonly occupied moist-soil emergent } \\
\text { wetlands and edges of seasonal or semipermanent } \\
\text { wetlands and lakes; breeding habitat was characterized by } \\
\text { shallow ( } \leq 15 \mathrm{~cm} \text { deep) water; high invertebrate } \\
\text { abundance; and } 40-70 \% \text { vegetative cover interspersed } \\
\text { with open water, mudflats, and/or matted vegetation; } \\
\text { nested in various species of robust emergent vegetation } \\
\text { (e.g., cattail or bulrush); nests were built on the surface of } \\
\text { the water, slightly submerged below, or }<15 \mathrm{~cm} \text { above the } \\
\text { water's surface; water depth at nest sites was usually }<30 \\
\text { cm, but ranged from } 0 \text { to } 71 \mathrm{~cm} \text {; nests were commonly } \\
\text { placed near a vegetative border, but not near open water }\end{array}$ \\
\hline
\end{tabular}




\begin{tabular}{|c|c|c|c|}
\hline Conway and Eddleman 1994 & Range-wide & Wetland & $\begin{array}{l}\text { Occurred in seasonal and semipermanent freshwater } \\
\text { wetlands with areas of dense (not defined), residual } \\
\text { vegetation interspersed with open water and mudflats; } \\
\text { optimal habitat was characterized by } 40-70 \% \text { (optimally } \\
60 \% \text { ) of the wetland in robust emergent vegetation } \\
\text { interspersed with open water, mudflat, or floating residual } \\
\text { vegetation mats; nested in various robust (e.g., cattail or } \\
\text { bulrush) emergent plant species }\end{array}$ \\
\hline Crowley 1994 & Massachusetts & Wetland & $\begin{array}{l}\text { Presence within wetlands was positively related to area of } \\
\text { cattail, area of fine-leaved emergents (e.g., sedges and } \\
\text { grasses), and water pH; presence was negatively related } \\
\text { to the number of human habitations within } 500 \text { m of } \\
\text { wetland edges; mean habitat values at } 230 \text { flush locations } \\
\text { were } 50 \% \text { cattail, } 31 \% \text { fine-leaved emergents, } 6 \% \text { shrub, } \\
4 \% \text { purple loosestrife (Lythrum salicaria), } 3 \% \text { scrub, } 2 \% \\
\text { cover of pickerelweed (Pontederia cordata)/arrowhead } \\
\text { (Sagittaria), } 2 \% \text { common reed (Phragmites australis), } 2 \% \\
\text { decodon (Decodon), and } 13.3 \text { cm water depth }\end{array}$ \\
\hline Daub 1993 & Manitoba & Wetland & $\begin{array}{l}\text { Were present in all wetland size classes examined }(<1 \\
\text { ha,1-2.9 ha, 3-5.9 ha, and 6-20 ha) }\end{array}$ \\
\hline Dault 2001 & Iowa & $\begin{array}{l}\text { Wetland, wetland } \\
\text { (restored) }\end{array}$ & $\begin{array}{l}\text { Nested on eight natural wetlands, three wetlands restored } \\
\text { for } 8-12 \text { yr, and one wetland restored for } 4-6 \text { yr; restored } \\
\text { wetlands older than } 12 \text { yr were not examined; rails were } \\
\text { most likely to be detected in natural wetlands, followed } \\
\text { by wetlands restored for } 8-12 \text { yr and wetlands restored for } \\
\text { 4-6 yr; presence was positively related to percent } \\
\text { emergent vegetation cover and to the number and total } \\
\text { area of wetlands within } 1500 \text { m of the surveyed wetland }\end{array}$ \\
\hline
\end{tabular}




\begin{tabular}{|c|c|c|c|}
\hline Delphey 1991 & Iowa & $\begin{array}{l}\text { Wetland, wetland } \\
\text { (restored) }\end{array}$ & Occurred in natural wetlands but not in restored wetlands \\
\hline Faanes 1981 & $\begin{array}{l}\text { Minnesota, } \\
\text { Wisconsin }\end{array}$ & $\begin{array}{l}\text { Stream, wet } \\
\text { meadow, wetland }\end{array}$ & $\begin{array}{l}\text { Greatest densities occurred in seasonal and } \\
\text { semipermanent wetlands dominated by cattail, river } \\
\text { bulrush (Schoenoplectus fluviatilis), and common reed; } \\
\text { occasionally nested along well-vegetated streams in sedge } \\
\text { meadow and in wetlands in shrub carr habitat }\end{array}$ \\
\hline Faanes 1982 & North Dakota & Wetland & $\begin{array}{l}\text { Nested in dense (not defined) emergent vegetation } \\
\text { associated with permanent wetlands }\end{array}$ \\
\hline Faanes and Lingle 1995 & Nebraska & Wetland & $\begin{array}{l}\text { Occurred in dense (not defined) emergent vegetation } \\
\text { along the perimeter of wetlands, such as hardstem bulrush } \\
\text { (Schoenoplectus acutus), cattail, and common reed }\end{array}$ \\
\hline Fairbairn and Dinsmore 2001a & Iowa & $\begin{array}{l}\text { Wetland, wetland } \\
\text { (restored) }\end{array}$ & $\begin{array}{l}\text { Were more likely to occur in natural than in restored } \\
\text { wetlands; occurrence was positively related to habitat } \\
\text { diversity (measure of the evenness of the distribution of } \\
\text { the vegetation zones [e.g., wet-meadow zone, } \\
\text { shallow-marsh zone, deep-marsh zone, open-water zone; } \\
\text { Stewart and Kantrud 1971]) and negatively related to } \\
\text { percent open water; densities were positively related to } \\
\text { the area of open water within the emergent vegetation } \\
\text { zone of the wetland and to percent emergent vegetation } \\
\text { cover }\end{array}$ \\
\hline Fairbairn and Dinsmore $2001 b$ & Iowa & Wetland & $\begin{array}{l}\text { Densities were positively associated with area of the } \\
\text { wetland dominated by wet-meadow vegetation and with } \\
\text { the area of open water within the emergent vegetation } \\
\text { zone of the wetland }\end{array}$ \\
\hline Fuller et al. 1979 & North Dakota & Wetland & One upland nest was found in a field seeded to native \\
\hline
\end{tabular}




\begin{tabular}{|c|c|c|c|}
\hline & & & $\begin{array}{l}\text { grasses and alfalfa (Medicago sativa), and it was } 25 \mathrm{~m} \\
\text { from the edge of a wetland }\end{array}$ \\
\hline Gibbs et al. 1991 & Maine & Wetland & $\begin{array}{l}\text { Occupied wetlands contained more hectares of vegetation } \\
\text { from the heath family (Ericaceae) than unoccupied } \\
\text { wetlands ( } 3.3 \text { ha vs. } 0.85 \text { ha); mean percent cover at eight } \\
\text { occupied wetlands averaged } 24 \% \text { floating or submerged } \\
\text { vegetation, } 22 \% \text { emergent vegetation, } 21 \% \text { open water, } \\
18 \% \text { ericaceous (Ericaceae) vegetation, } 12 \% \text { alder } \\
\text { (Alnus), and } 8 \% \text { timber; occupied wetlands averaged } 17.8 \\
\text { ha in size, } 734 \mathrm{~m} \text { to the next nearest wetland, } 365 \mathrm{~m} \text { to the } \\
\text { nearest road, } 6.57 \mathrm{pH} \text {, and } 47.36 \mu \text { s conductivity }\end{array}$ \\
\hline Glahn 1974 & Colorado & Wetland & $\begin{array}{l}\text { Territories were dominated by cattail; } 15 \text { of } 18 \text { territories } \\
\text { were bordered by bulrush, common spikerush (Eleocharis } \\
\text { palustris), saltgrass, and mudflat and three territories } \\
\text { were entirely within cattail; nests were constructed of and } \\
\text { supported by cattail; seven of nine nests were } \leq 15 \mathrm{~m} \text { from } \\
\text { a vegetation edge along territory boundaries and two were } \\
>15 \text { m from a vegetation edge }\end{array}$ \\
\hline Graetz et al. 1997 & Wisconsin & Wetland & $\begin{array}{l}\text { Were more common in cattail stands (10-19 individuals } \\
\text { detected during } 10 \text { surveys) than in sedge stands ( } 7-8 \\
\text { individuals), stands of multiple plant species ( } 4-13 \\
\text { individuals), or bulrush stands ( } 0 \text { individuals) }\end{array}$ \\
\hline Griese 1977, Griese et al. 1980 & Colorado & $\begin{array}{l}\text { Impoundment, wet } \\
\text { meadow, wetland }\end{array}$ & $\begin{array}{l}\text { Occupied wetlands and impoundments from } 1120 \text { to } 2730 \\
\mathrm{~m} \text { in elevation; preferred wetlands dominated by cattail } \\
\text { with shallow water ( } \leq 15 \mathrm{~cm} \text { deep) for breeding; water } \\
\text { depth averaged } 7.1 \mathrm{~cm} \text { at nine nests; rails also used wet } \\
\text { meadows and wet meadows associated with irrigated } \\
\text { hayfields at upper ( }>2600 \mathrm{~m} \text { ) elevations }\end{array}$ \\
\hline
\end{tabular}




\begin{tabular}{|c|c|c|c|}
\hline Hartman 1994 & Indiana & $\begin{array}{l}\text { Wetland, wetland } \\
\text { (restored) }\end{array}$ & $\begin{array}{l}\text { Occurred in one of seven natural wetlands and in five of } \\
26 \text { restored wetlands; nested in two of } 26 \text { restored } \\
\text { wetlands; no nests were found in natural wetlands }\end{array}$ \\
\hline Horak 1964 & Iowa & $\begin{array}{l}\text { Wet meadow, } \\
\text { wetland }\end{array}$ & $\begin{array}{l}\text { Of } 21 \text { nests, } 14 \text { were located in cattail, three in hairy } \\
\text { whitetop (Cardaria pubescens), two in reed (Phragmites } \\
\text { sp.), and two in sedges; of } 21 \text { nests, } 11 \text { were made of } \\
\text { cattail, five of sedges, and five of hairy whitetop; } \\
\text { vegetation coverage averaged } 67 \% \text { cattail, } 14 \% \text { hairy } \\
\text { whitetop, } 10 \% \text { phragmites, and } 9 \% \text { sedge; vegetation } \\
\text { height at nests averaged } 119 \mathrm{~cm} \text { and ranged from } 61 \text { to } \\
183 \mathrm{~cm} \text {; water depth at nest sites averaged } 41 \mathrm{~cm} \text { and } \\
\text { ranged from } 10 \text { to } 71 \mathrm{~cm} \text {; ramps leading up to the nest rim } \\
\text { were rarely observed }\end{array}$ \\
\hline Johnsgard 1979, 1980 & Great Plains & Wetland & $\begin{array}{l}\text { Nested in wetlands with extensive stands of emergent } \\
\text { vegetation (cattails, common reed, bulrush [Scirpus spp.], } \\
\text { and sedge); nests were built on wet ground or over } \\
\text { shallow (not defined) water in emergent vegetation }\end{array}$ \\
\hline $\begin{array}{l}\text { Johnson 1984; } \\
\text { Johnson and Dinsmore 1985, } \\
1986\end{array}$ & Iowa & Wetland & $\begin{array}{l}\text { Occupied sites with standing water; mean distances of } \\
147 \text { territory centers to nearest physiographic features } \\
\text { were } 29.5 \mathrm{~m} \text { to open water, } 17.1 \mathrm{~m} \text { to upland, } 38.4 \mathrm{~m} \text { to a } \\
\text { vegetation interface, and } 12.9 \mathrm{~m} \text { to a cattail stand; } \\
\text { preferred sedges, hardstem bulrush, and bur-reed over } \\
\text { cattail, river bulrush, and other wetland vegetation; in the } \\
\text { first year of study, mean percent coverages of emergent } \\
\text { vegetation for } 371 \text { occupied sites were } 50 \% \text { cattail, } 22 \% \\
\text { bur-reed, } 18 \% \text { sedges, } 5 \% \text { miscellaneous, } 4 \% \text { hardstem } \\
\text { bulrush, and } 1 \% \text { river bulrush; in the second year, mean } \\
\text { percent coverages of emergent vegetation for } 320 \\
\text { occupied sites were } 66 \% \text { cattail, } 17 \% \text { sedges, } 7 \%\end{array}$ \\
\hline
\end{tabular}




\begin{tabular}{|c|c|c|c|}
\hline & & & $\begin{array}{l}\text { miscellaneous, 5\% bur-reed, } 3 \% \text { river bulrush, and } 2 \% \\
\text { hardstem bulrush; mean vegetation measurements of } 957 \\
\text { quadrats on } 92 \text { territories were } 131.3 \mathrm{~cm} \text { visual } \\
\text { obstruction, } 116 \text { stems } / \mathrm{m}^{2}, 40.3 \mathrm{~cm} \text { water depth, and a } \\
\text { category } 2.4 \text { (scale of } 0-4 \text { indicating low to high amounts) } \\
\text { for amount of floating or submersed residual vegetation; } \\
\text { mean frequency of occurrence of emergent plant species } \\
\text { on } 957 \text { quadrats at } 92 \text { territories was } 73 \% \text { cattail, } 53 \% \\
\text { sedges, } 45 \% \text { bur-reed, } 41 \% \text { knotweed (Polygonum spp.), } \\
14 \% \text { river bulrush, } 12 \% \text { hardstem bulrush, } 12 \% \\
\text { arrowhead, } 3 \% \text { miscellaneous, and } 0.1 \% \text { common reed; } \\
\text { estimated brood-rearing home range size for nine rails } \\
\text { (both sexes combined) was } 0.18 \text { ha; brood-rearing home } \\
\text { range sizes for five males and four females were } 0.16 \text { ha } \\
\text { and } 0.22 \text { ha, respectively; mean distance moved between } \\
\text { locations for nine rails was } 43 \text { m; breeding home ranges } \\
\text { were bounded by open water and upland }\end{array}$ \\
\hline Kantrud and Higgins 1992 & $\begin{array}{l}\text { Manitoba, } \\
\text { Montana, } \\
\text { North Dakota, } \\
\text { South Dakota }\end{array}$ & $\begin{array}{l}\text { Wet meadow, } \\
\text { wetland }\end{array}$ & $\begin{array}{l}\text { Nested in wet-meadow zones of wetlands; prairie } \\
\text { cordgrass dominated eight of } 10 \text { nest sites and forbs } \\
\text { (species not specified) surrounded the other two nest } \\
\text { sites; all nest sites had visual obstruction readings of at } \\
\text { least } 10 \mathrm{~cm}\end{array}$ \\
\hline Kantrud and Stewart 1984 & North Dakota & Wetland complex & $\begin{array}{l}\text { Highest density was in fens, followed by semipermanent } \\
\text { and seasonal wetlands }\end{array}$ \\
\hline Kaufmann 1971, 1989 & $\begin{array}{l}\text { Iowa, } \\
\text { Minnesota }\end{array}$ & Wetland & $\begin{array}{l}\text { Of } 141 \text { nests, } 100 \text { were in robust vegetation (e.g., cattail), } \\
28 \text { were in fine vegetation (e.g., sedges), and } 13 \text { were } \\
\text { stands of multiple plant species }\end{array}$ \\
\hline Manci and Rusch 1988, 1989 & Wisconsin & Wetland & Densities were higher in deep-water cattail habitat \\
\hline
\end{tabular}




\begin{tabular}{|c|c|c|c|}
\hline & & & $\begin{array}{l}\text { (characterized by a mean water depth of } 29 \mathrm{~cm} \text { ) than in } \\
\text { shallow-water cattail habitat (characterized by mean } \\
\text { water depths of } 7-10 \mathrm{~cm} \text { ) or in shallow-water river } \\
\text { bulrush habitat (characterized by mean water depths of 7- } \\
10 \mathrm{~cm} \text { ) }\end{array}$ \\
\hline Mousley 1937 & $\begin{array}{l}\text { Canada } \\
\text { (province not } \\
\text { given) }\end{array}$ & Wetland & $\begin{array}{l}\text { One nest was composed of cattail and grasses (species not } \\
\text { given) and was located in growing cattails; the nest rim } \\
\text { was } 16.5 \mathrm{~cm} \text { above water }\end{array}$ \\
\hline Mousley 1940 & $\begin{array}{l}\text { Canada } \\
\text { (province not } \\
\text { given) }\end{array}$ & Wetland & Nested in cattails, sedges, and rushes \\
\hline $\begin{array}{l}\text { Naugle 1997, } \\
\text { Naugle et al. } 2001\end{array}$ & South Dakota & Wetland & $\begin{array}{l}\text { Presence in seasonal and semipermanent wetlands was } \\
\text { positively related to percent of wetland area that was } \\
\text { vegetated and to the abundance of thick-stemmed plants } \\
\text { (e.g., cattail) }\end{array}$ \\
\hline $\begin{array}{l}\text { Pospichal 1952, } \\
\text { Pospichal and Marshall } 1954\end{array}$ & Minnesota & Wetland & $\begin{array}{l}\text { Nested in cattail near (not quantified) open water or near } \\
\text { an edge between two vegetation cover types; nests were } \\
\text { either in contact with the surface of the water or extended } \\
\text { slightly below the water's surface; multiple inactive nests } \\
\text { were constructed and served as resting and feeding } \\
\text { platforms; mean nest measurements for } 12 \text { nests were } \\
12.8 \mathrm{~cm} \text { (range of } 5 \text { - } 21 \mathrm{~cm} \text { ) height of nest rim above } \\
\text { water and } 21.2 \mathrm{~cm} \text { (range of } 12-44 \mathrm{~cm} \text { ) water depth }\end{array}$ \\
\hline Prescott et al. 2001 & Alberta & Wetland & $\begin{array}{l}\text { Were detected more often in permanent or semipermanent } \\
\text { wetlands than in seasonal wetlands; } 35 \text { occupied wetlands } \\
\text { had more open water ( } 32.1 \% \text { vs. } 23.5 \% \text { ) and less shrub } \\
(5.1 \% \text { vs. } 9.9 \% \text { ) than } 369 \text { unoccupied wetlands }\end{array}$ \\
\hline
\end{tabular}




\begin{tabular}{|c|c|c|c|}
\hline Ribic 1999 & Wisconsin & Wetland & $\begin{array}{l}\text { Were more likely to be detected (using call playback } \\
\text { surveys) in areas dominated by cattail than in areas } \\
\text { dominated by sedges }\end{array}$ \\
\hline Provost 1947 & Iowa & Wetland & $\begin{array}{l}\text { Nested in hairy sedge (Carex lacustris); nests were } \\
\text { constructed of hairy sedge and were protected by a } \\
\text { canopy of vegetation; two nests were } 10 \mathrm{~cm} \text { above water } \\
\text { that was } 33 \mathrm{~cm} \text { deep and were placed } 18-25 \mathrm{~m} \text { from open } \\
\text { water }\end{array}$ \\
\hline Rundle and Fredrickson 1981 & Missouri & Impoundment & $\begin{array}{l}\text { Water depths at eight flush locations ranged from } 0 \text { to } 27 \\
\mathrm{~cm} \text { and averaged } 7.3 \mathrm{~cm} \text {; most rails ( } 6 \text { of } 8 \text { ) occurred in } \\
\text { water } \leq 15 \mathrm{~cm} \text { deep; were most common in a moist-soil } \\
\text { impoundment with water depths of } 5-15 \mathrm{~cm} \text { and mixed } \\
\text { stands of beggarticks (Bidens spp.), lateflowering } \\
\text { thoroughwort (Eupatorium serotinum), and barnyard } \\
\text { grass (Echinochloa muricata and E. crusgalli) }\end{array}$ \\
\hline Sayre and Rundle 1984 & Missouri & Impoundment & $\begin{array}{l}\text { Overall, water depths ranged from } 0 \text { to } 29.7 \mathrm{~cm} \text { at } 27 \\
\text { spring and fall flush sites, and } 70 \% \text { of } 27 \text { flush sites had } \\
<5 \mathrm{~cm} \text { of water. During spring migration, mean water } \\
\text { depth at } 14 \text { flush locations was } 5 \mathrm{~cm} \text { and mean vegetation } \\
\text { height was } 32 \mathrm{~cm} \text {; of } 11 \text { rails, seven were flushed from } \\
\text { water }<5 \mathrm{~cm} \text { deep, three were flushed from water } 5-15 \mathrm{~cm} \\
\text { deep, and one was flushed from water }>15 \mathrm{~cm} \text { deep; six } \\
\text { of } 11 \text { rails were flushed from vegetation }<30 \mathrm{~cm} \text { tall and } \\
\text { five were flushed from vegetation }>30 \mathrm{~cm} \text { tall; eight of } 11 \\
\text { rails were flushed from dense (number of contacts with a } \\
\text { point-intercept sampling rod was }>30 \text { ) vegetation and } \\
\text { three were flushed from sparse ( } 5-30 \text { contacts) vegetation; } \\
\text { plant species associated with spring use sites included } \\
\text { beggartick, broomsedge (Andropogon virginicus), sedges }\end{array}$ \\
\hline
\end{tabular}




\begin{tabular}{|c|c|c|c|}
\hline & & & $\begin{array}{l}\text { (Carex spp. and Cyperus spp.), and rushes. } \\
\text { During fall migration, mean water depth at } 13 \text { flush } \\
\text { locations was } 2.4 \mathrm{~cm} \text { and mean vegetation height was } 39 \\
\mathrm{~cm} \text {; of eight rails, seven were flushed from water }<5 \mathrm{~cm} \\
\text { deep and one was flushed from water } 5-15 \mathrm{~cm} \text { deep; five } \\
\text { of eight rails were flushed from vegetation }>30 \mathrm{~cm} \text { tall } \\
\text { and three were flushed from vegetation }<30 \mathrm{~cm} \text { tall; seven } \\
\text { of eight rails were flushed from dense vegetation and one } \\
\text { was flushed from sparse vegetation; vegetation species } \\
\text { associated with fall use sites included beggartick, } \\
\text { lateflowering thoroughwort, and annual grasses such as } \\
\text { panicgrass (Panicum sp.), and crabgrass (Digitaria sp. } \\
\text { and Echinochloa spp.) }\end{array}$ \\
\hline Schreiber 1994 & Iowa & $\begin{array}{l}\text { Wetland, wetland } \\
\text { (restored) }\end{array}$ & $\begin{array}{l}\text { Frequency of occurrence was significantly greater in } \\
\text { natural wetlands than in restored wetlands }\end{array}$ \\
\hline Schuster 1998 & Iowa & $\begin{array}{l}\text { Wetland, wetland } \\
\text { (restored) }\end{array}$ & $\begin{array}{l}\text { Nested in both natural and restored wetlands (numbers of } \\
\text { nests not given) }\end{array}$ \\
\hline Stabler and Kitzmiller 1971 & Colorado & Wetland & $\begin{array}{l}\text { One nest was located in dense (not defined) broad-leaved } \\
\text { cattail (Typha latifolia); the nest was } 30.5 \mathrm{~cm} \text { above water } \\
\text { that was } 41 \mathrm{~cm} \text { deep, was constructed of dead cattail } \\
\text { leaves, and was secured to adjacent cattail stems }\end{array}$ \\
\hline Stewart 1975 & North Dakota & $\begin{array}{l}\text { Idle mixed-grass, } \\
\text { idle tallgrass, wet } \\
\text { meadow, wetland }\end{array}$ & $\begin{array}{l}\text { Nested in fens, seasonal wetlands, and fresh to brackish } \\
\text { and subsaline semipermanent wetlands with moderately } \\
\text { dense (not defined) stands of emergent vegetation; nests } \\
\text { were usually partially domed with emergent stems and } \\
\text { leaves; nested in stands of hardstem bulrush, a mixture of } \\
\text { alkali bulrush and foxtail barley (Hordeum jubatum), and }\end{array}$ \\
\hline
\end{tabular}




\begin{tabular}{|c|c|c|c|}
\hline & & & $\begin{array}{l}\text { in alkali bulrush; one nest was found in upland prairie, } \\
\text { several meters away from the wet-meadow zone of a } \\
\text { wetland; water depth at three nest sites were } 0 \mathrm{~cm} \text { (wet } \\
\text { ground), } 7.6 \mathrm{~cm} \text {, and } 19 \mathrm{~cm}\end{array}$ \\
\hline Stewart and Kantrud 1965 & North Dakota & Wetland & $\begin{array}{l}\text { Commonly occupy fresh through brackish semipermanent } \\
\text { wetlands with either closed stands of emergent cover, } \\
\text { clumps of emergent cover interspersed with open water, } \\
\text { or with centrally located expanses of open water } \\
\text { surrounded by peripheral bands of emergent vegetation }\end{array}$ \\
\hline Svedarsky 1992 & Minnesota & $\begin{array}{l}\text { Impoundment, } \\
\text { wetland, wetland } \\
\text { (restored) }\end{array}$ & $\begin{array}{l}\text { One nest was located in a restored wetland in a stand of } \\
\text { hardstem bulrush, cattail, and sedge; the nest was } 25 \mathrm{~cm} \\
\text { above water that was } 27 \mathrm{~cm} \text { deep }\end{array}$ \\
\hline Tacha 1975 & Kansas & $\begin{array}{l}\text { Wetland, wetland } \\
\text { complex }\end{array}$ & $\begin{array}{l}\text { Occupied areas were dominated by alkali bulrush, cattail, } \\
\text { softstem bulrush, prairie cordgrass, and inland saltgrass } \\
\text { and were in areas with water } 0 \text { to } 15 \mathrm{~cm} \text { deep; of nine } \\
\text { nests, five were constructed of dried grasses, sedges, or } \\
\text { cattail and were above } 3 \mathrm{~cm} \text { of water; the remaining four } \\
\text { nests were situated on or above dry ground }\end{array}$ \\
\hline $\begin{array}{l}\text { Tanner 1953, } \\
\text { Tanner and Hendrickson } 1954\end{array}$ & Iowa & Wetland & $\begin{array}{l}\text { Dominant vegetation at } 37 \text { nest sites was hairy sedge (24), } \\
\text { hardstem bulrush and slender bulrush (Schoenoplectus } \\
\text { heterochaetus) (four), river bulrush (four), cattail (three), } \\
\text { sprangletop (Scolochloa festucacea) (one), and bluejoint } \\
\text { (one); water depth at } 27 \text { nests ranged from } 15 \text { to } 46 \mathrm{~cm} \\
\text { and averaged } 31 \mathrm{~cm} \text {; water depths at eight nests ranged } \\
\text { from } 29 \text { to } 56 \mathrm{~cm} \text { and averaged } 38 \mathrm{~cm}\end{array}$ \\
\hline $\begin{array}{l}\text { VanRees-Siewert 1993, } \\
\text { VanRees-Siewert and }\end{array}$ & Iowa & $\begin{array}{l}\text { Wetland, wetland } \\
\text { (restored) }\end{array}$ & $\begin{array}{l}\text { Nested in one of six 2-yr-old restored wetlands and two of } \\
\text { six } 4 \text {-yr-old restored wetlands; were present on wetlands } \\
\text { restored for 1-4 yr (the study did not examine restored }\end{array}$ \\
\hline
\end{tabular}




\begin{tabular}{|c|c|c|c|}
\hline Dinsmore 1996 & & & $\begin{array}{l}\text { wetlands older than } 4 \text { yr); occurrence increased with } \\
\text { wetland age }\end{array}$ \\
\hline Vogel 1999 & Missouri & $\begin{array}{l}\text { Impoundment, } \\
\text { lake, wetland }\end{array}$ & $\begin{array}{l}\text { Mean habitat measurements at eight flush sites were } 10 \% \\
\text { basal green vegetation cover, } 43.3 \% \text { basal litter cover, } \\
13.3 \% \text { green vegetation cover at } 15 \mathrm{~cm}, 23.3 \% \text { litter cover } \\
\text { at } 15 \mathrm{~cm}, 43.3 \% \text { total overhead vegetation cover, and } 37.7 \\
\mathrm{~cm} \text { vegetation height; water depth ranged from } 0 \text { to } 8 \mathrm{~cm} \\
\text { and averaged } 2.4 \mathrm{~cm} \text {; flush sites were dominated by river } \\
\text { bulrush, knotweed, or common buttonbush (Cephalanthus } \\
\text { occidentalis) }\end{array}$ \\
\hline Walkinshaw 1937 & Michigan & Lake, wetland & $\begin{array}{l}\text { Nested in bulrush along the margin of a lake and in sedge, } \\
\text { cattail, swamp loosestrife (Decodon verticillatis), and } \\
\text { common reed in wetlands; } 44 \text { nests averaged about } 14 \mathrm{~cm} \\
\text { above the surface of the water; water depth at } 44 \text { nest } \\
\text { sites ranged from } 10 \text { to } 25 \mathrm{~cm} \text {; nests were usually covered } \\
\text { by a canopy of rushes or sedges }\end{array}$ \\
\hline Weller and Fredrickson 1973 & Iowa & Wetland & $\begin{array}{l}\text { Density peaked the year of reflooding, which coincided } \\
\text { with the growth of sparse and well-dispersed annuals and } \\
\text { immature perennials; density then declined for three years } \\
\text { as a dense bed of perennials became established, and } \\
\text { finally increased again for the next two years as the } \\
\text { wetland approached a vegetation-to-open water ratio of } \\
\text { 50:50; rails occurred in the peripheral emergent } \\
\text { vegetation of the wetland }\end{array}$ \\
\hline \multirow[t]{2}{*}{ Whitt et al. 1999} & Michigan & $\begin{array}{l}\text { Wet meadow, } \\
\text { wetland }\end{array}$ & $\begin{array}{l}\text { Occurred in wet meadow, cattail, shrub, and purple } \\
\text { loosestrife habitats; nested in an area dominated by purple } \\
\text { loosestrife }\end{array}$ \\
\hline & & & Nested in cattail about $15 \mathrm{~cm}$ above the surface of the \\
\hline
\end{tabular}




\begin{tabular}{|l|l|l|l|}
\hline Wood 1937 & Pennsylvania & Wetland & water \\
\hline Zimmerman 1977 & Range-wide & Wetland & $\begin{array}{l}\text { Nested in sedge and cattail at the borders of freshwater } \\
\text { wetlands; may use wetlands as small as 0.2 ha; } \\
\text { occasionally nest in smooth cordgrass (Spartina } \\
\text { alterniflora) in saltwater marshes; nests were located } \\
\text { from 5 to 13 cm above the water and water depths at nest } \\
\text { sites were generally 8-25 cm }\end{array}$ \\
\hline Zimmerman 1984 & Kansas & $\begin{array}{l}\text { Impoundment, } \\
\text { lake, wetland }\end{array}$ & $\begin{array}{l}\text { Water depth at 14 occupied sites averaged 9.9 cm; at 43 } \\
\text { occupied sites, water depths ranged from 7 to 27.7 cm, } \\
\text { mean vegetation heights ranged from 56.9 to 109.8 cm, } \\
\text { and mean percent open water ranged from 9.8 to 33.9\% }\end{array}$ \\
\hline
\end{tabular}




\section{LITERATURE CITED}

Allen, A. A. 1934. The Virginia Rail and the Sora. Bird Lore 36:196-204.

Allen, G. T., and P. Ramirez. 1990. A review of bird deaths on barbed-wire fences. Wilson Bulletin 102:553-558.

Andrews, D. A. 1973. Habitat utilization by Sora, Virginia Rails and King Rails near southwestern Lake Erie. M.S. thesis. Ohio State University, Columbus, Ohio. 112 pages.

Avery, M., and T. Clement. 1972. Bird mortality at four towers in eastern North Dakota-fall 1972. Prairie Naturalist 4:87-95.

Baird, K. E. 1974. A field study of the King, Sora and Virginia rails at Cheyenne Bottoms in west-central Kansas. M.S. thesis. Kansas State University, Manhattan, Kansas. 38 pages.

Batts, H. L., Jr. 1958. The distribution and population of nesting birds on a farm in southern Michigan. Jack-Pine Warbler 36:131-149.

Beattie, F. N. 1899. Nesting of the Virginia Rail. Oologist 16:184.

Bent, A. C. 1963. Life histories of North American marsh birds. Dover Publications, Inc., New York, New York. 392 pages.

Berger, A. J. 1951. Nesting density of Virginia and Sora rails in Michigan. Condor 53:202.

Beule, J. D. 1979. Control and management of cattails in southeastern Wisconsin wetlands. Wisconsin Department of Natural Resources, Madison, Wisconsin. Technical Bulletin No. 112. 39 pages.

Billard, R. S. 1948. An ecological study of the Virginia Rail and the Sora in some Connecticut swamps, 1947. M.S. thesis. Iowa State College, Ames, Iowa. 84 pages.

Boyer, G. F., and O. E. Devitt. 1961. A significant increase in the birds of Luther Marsh, Ontario, following freshwater impoundment. Canadian Field-Naturalist 75:225-237.

Brady, E. N. 1983. Birds on modified wetlands in eastern South Dakota. M.S. thesis. South Dakota State University, Brookings, South Dakota. 39 pages.

Brown, M., and J. J. Dinsmore. 1986. Implications of marsh size and isolation for marsh bird management. Journal of Wildlife Management 50:392-397.

Burtch, V. 1917. The summer life of the Virginia Rail. Bird Lore 19:243-248. 
Conway, C. J. 1990. Seasonal changes in movements and habitat use by three sympatric species of rails. M.S. thesis. University of Wyoming, Laramie, Wyoming. 58 pages.

Conway, C. J. 1995. Virginia Rail (Rallus limicola). A. Poole and F. Gill, editors. The birds of North America, No. 173. The Academy of Natural Sciences, Philadelphia, Pennsylvania; The American Ornithologists’ Union, Washington, D.C.

Conway, C. J., and W. R. Eddleman. 1994. Virginia Rail. Pages 193-206 in T. C. Tacha and C. E. Braun, editors. Management of migratory shore and upland game birds in North America. International Association of Fish and Wildlife Agencies, Washington, D.C.

Cooke, W. W. 1914. Distribution and migration of North American rails and their allies. Bulletin of the U.S. Department of Agriculture 128.

Crawford, R. L. 1974. Bird casualties at a Leon County, Florida TV tower: October 1966September 1973. Bulletin of the Tall Timbers Research Station. No. 18. 27 pages.

Crowley, S. K. 1994. Habitat use and population monitoring of secretive waterbirds in Massachusetts. M.S. thesis. University of Massachusetts, Amherst, Massachusetts. 108 pages.

Daub, B. C. 1993. Effects of marsh area and characteristics on avian diversity and nesting success. M.S. thesis. University of Michigan, Ann Arbor, Michigan. 37 pages.

Dault, R. E. 2001. Long-term effects of wetland restoration on bird communities in the Prairie Pothole Region of northwestern Iowa. M.S. thesis. Iowa State University, Ames, Iowa. 107 pages.

Delphey, P. J. 1991. A comparison of the bird and aquatic macroinvertebrate communities between restored and 'natural' Iowa prairie wetlands. M.S. thesis. Iowa State University, Ames, Iowa. 85 pages.

Faanes, C. A. 1981. Birds of the St. Croix River Valley: Minnesota and Wisconsin. U.S. Fish and Wildlife Service, Washington, D.C. North American Fauna 73. 196 pages.

Faanes, C. A. 1982. Avian use of Sheyenne Lake and associated habitats in central North Dakota. U.S. Fish and Wildlife Service, Resource Publication 144. 24 pages.

Faanes, C. A., and G. R. Lingle. 1995. Breeding birds of the Platte River Valley of Nebraska. Northern Prairie Wildlife Research Center home page. http://www.npwrc.usgs.gov/resource/distr/birds/platte/platte.htm (Version 02SEP99).

Fairbairn, S. E., and J. J. Dinsmore. 2001a. Factors associated with occurrence and density of wetland birds in the Prairie Pothole Region of Iowa. Journal of the Iowa Academy of 
Science 108:8-14.

Fairbairn, S. E., and J. J. Dinsmore. 2001b. Local and landscape-level influence on wetland bird communities of the Prairie Pothole Region of Iowa, USA. Wetlands 21:41-47.

Fredrickson, L. H., and F. A. Reid. 1986. Wetland and riparian habitats: a nongame management overview. Pages 59-96 in J. B. Hale, L. B. Best, and R. L. Clawson, editors. Management of nongame wildlife in the Midwest: a developing art. North Central Section Wildlife Society, Chelsea, Michigan.

Friedmann, H., L. F. Kiff, and S. I. Rothstein. 1977. A further contribution to knowledge of the host relations of the parasitic cowbirds. Smithsonian Contributions to Zoology 235:1-75.

Fuller, T. L., B. Reiswig, K. A. Smith, and R. A. Stromstad. 1979. An upland nest of the Virginia Rail in North Dakota. Prairie Naturalist 11:9.

Gibbs, J. P., J. R. Longcore, D. G. McAuley, and J. K. Ringleman. 1991. Use of wetland habitats by selected nongame birds in Maine. U.S. Fish and Wildlife Service, Fish and Wildlife Research Report No. 9. 57 pages.

Gillette, D. C. 1897. Notes on the Virginia and Sora rails. Oologist 14:21-23.

Glahn, J. F. 1974. Study of breeding rails with recorded calls in north-central Colorado. Wilson Bulletin 86:206-214.

Graetz, J. L., S. W. Matteson, J. Skoloda, and C. Ribic. 1997. Status and distribution of marsh and sedge meadow birds at Horican, Necedah, and Trempealeau national wildlife refuges. Passenger Pigeon 59:119-130.

Griese, H. J. 1977. Status and habitat utilization of rails in Colorado. M.S. thesis. Colorado State University, Fort Collins, Colorado. 67 pages.

Griese, H. J., R. A. Ryder, and C. E. Braun. 1980. Spatial and temporal distribution of rails in Colorado. Wilson Bulletin 92:96-102.

Griffing, M. B. 1881. Virginia Rail. Ornithologist and Oologist 6:59.

Hanowski, J. M., G. J. Niemi, R. Lima, and R. R. Regal. 1997. Response of breeding birds to mosquito control treatments of wetlands. Wetlands 17:485-492.

Hartman, M. R. 1994. Avian use of restored and natural wetlands in northcentral Indiana. M.S. thesis. Purdue University, West Lafayette, Indiana. 98 pages.

Hathorn, G. M. 1902. The Virginia Rail. Oologist 19:161-162. 
Hemesath, L. M. 1991. Species richness and nest productivity of marsh birds on restored prairie potholes in northern Iowa. M.S. thesis. Iowa State University, Ames, Iowa. 87 pages.

Hemesath, L. M., and J. J. Dinsmore. 1993. Factors affecting bird colonization of restored wetlands. Prairie Naturalist 25:1-11.

Hersey, F. S. 1910. A Virginia Rail nesting. Oologist 27:44-45.

Holliman, D. C. 1977. Rails and gallinules. Pages 118-121 in G. C. Sanderson, editor. Management of migratory shore and upland game birds in North America. International Association of Fish and Wildlife Agencies, Washington, D.C.

Horak, G. J. 1964. A comparative study of Virginia and Sora rails with emphasis on foods. M.S. thesis. Iowa State University, Ames, Iowa. 73 pages.

Janssen, R. B. 1987. Birds in Minnesota. University of Minnesota Press, Minneapolis, Minnesota. 352 pages.

Johnsgard, P. A. 1979. Birds of the Great Plains. University of Nebraska Press, Lincoln, Nebraska. 539 pages.

Johnsgard, P. A. 1980. A preliminary list of the birds of Nebraska and adjacent Plains states. University of Nebraska, Lincoln, Nebraska. 156 pages.

Johnson, R. R. 1984. Breeding habitat use and postbreeding movements by Soras and Virginia Rails. M.S. thesis. Iowa State University, Ames, Iowa. 52 pages.

Johnson, R. R., and J. J. Dinsmore. 1985. Brood-rearing and postbreeding habitat use by Virginia Rails and Soras. Wilson Bulletin 97:551-554.

Johnson, R. R., and J. J. Dinsmore. 1986. Habitat use by breeding Virginia Rails and Soras. Journal of Wildlife Management 50:387-392.

Kantrud, H. A., and K. F. Higgins. 1992. Nest and nest site characteristics of some groundnesting, non-passerine birds of northern grasslands. Prairie Naturalist 24:67-84.

Kantrud, H. A., and R. E. Stewart. 1984. Ecological distribution and crude density of breeding birds on prairie wetlands. Journal of Wildlife Management 48:426-437.

Kaufmann, G. W. 1971. Behavior and ecology of the Sora, Porzana carolina, and Virginia Rail, Rallus limicola. Ph.D. dissertation. University of Minnesota, Minneapolis, Minnesota. 114 pages. 
Kaufmann, G. W. 1989. Breeding ecology of the Sora, Porzana carolina, and the Virginia Rail, Rallus limicola. Canadian Field-Naturalist 103:270-282.

Kent, T. H., and J. J. Dinsmore. 1996. Birds in Iowa. Published by the authors, Iowa City and Ames, Iowa. 391 pages.

Krapu, G. L., and R. K. Green. 1978. Breeding bird populations of selected semipermanent wetlands in south-central North Dakota-1977. American Birds 32:110-112.

Lindmeier, J. P. 1960. Plover, rail and godwit nesting on a study area in Mahnomen County, Minnesota. Flicker 32:5-9.

Lowther, J. K. 1961. Virginia Rail (Rallus limicola limicola) breeding at Vermilion, Alberta. Auk 78:271.

Malcolm, J. M. 1982. Bird collisions with a power transmission line and their relation to botulism at a Montana wetland. Wildlife Society Bulletin 10:297-304.

Manci, K. M., and D. H. Rusch. 1988. Indices to distribution and abundance of some inconspicuous waterbirds on Horicon Marsh. Journal of Field Ornithology 59:67-75.

Manci, K. M., and D. H. Rusch. 1989. Waterbird use of wetland habitats identified by infrared aerial photography. Pages 1045-1058 in R. R. Sharitz and J. W. Gibbons, editors. Freshwater wetlands and wildlife. Proceedings of a symposium held at Charleston, South Carolina, March 24-27, 1986. U.S. Department of Energy, Office of Scientific and Technical Information, Oak Ridge, Tennessee.

Marshall, W. H. 1952. Waterfowl of three prairie potholes. Flicker 24:60-68.

Meeks, R. L. 1968. The accumulation of ${ }^{36} \mathrm{C} 1$ ring-labeled DDT in a freshwater marsh. Journal of Wildlife Management 32:376-398.

Miller, R. F. 1928. Virginia Rail lays in Sora’s nest. Oologist 45:132.

Mousley, H. 1931. Notes on the home life of the Virginia Rail. Canadian Field-Naturalist 45:65-66.

Mousley, H. 1937. A study of a Virginia Rail and Sora Rail at their nests. Wilson Bulletin 49:80-84.

Mousley, H. 1940. Further notes on the nesting habits of the Virginia Rail. Wilson Bulletin 52:87-90.

National Geographic Society. 1999. Field guide to the birds of North America, third edition. 
National Geographic Society, Washington, D.C. 480 pages.

Naugle, D. E. 1997. Habitat area requirements of prairie wetland birds in eastern South Dakota. Ph.D. dissertation. South Dakota State University, Brookings, South Dakota. 85 pages.

Naugle, D. E., R. R. Johnson, and K. F. Higgins. 2001. A landscape approach to conserving wetland bird habitat in the Prairie Pothole Region of eastern South Dakota. Wetlands 21:1-17.

Odom, R. R. 1975. Mercury contamination in Georgia rails. Proceedings of the Annual Conference of the Southeastern Association of Game and Fish Commissioners 28:649658.

Parmelee, D. F., M. D. Schwilling, and H. A. Stephens. 1970. Gruiform birds of Cheyenne Bottoms. Kansas Ornithological Society Bulletin 21:25-27.

Pospichal, L. B. 1952. A field study of Sora Rail (Porzana carolina) and Virginia Rail (Rallus limicola) populations in central Minnesota. M.S. thesis. University of Minnesota, St. Paul, Minnesota. 80 pages.

Pospichal, L. B., and W. H. Marshall. 1954. A field study of Sora Rail and Virginia Rail in central Minnesota. Flicker 26:2-32.

Post, W., and F. Enders. 1970. Notes on a saltmarsh Virginia Rail population. Kingbird 20:6167.

Prescott, D. R. C., M. R. Norton, and I. M. G. Michaud. 2001. A survey of Yellow and Virginia rails in Alberta using nocturnal call playbacks. Unpublished report by the Alberta Conservation Association, Edmonton, Alberta. 20 pages.

Provost, M. W. 1947. Nesting of birds in the marshes of northwest Iowa. American Midland Naturalist 38:485-503.

Pulich, W. M. 1961. A record of the Yellow Rail from Dallas County, Texas. Auk 78:639-640.

Randall, T. E. 1946. Virginia Rail, Rallus limicola limicola, nesting in Alberta. Canadian Field-Naturalist 60:135.

Ribic, C. A. 1999. Rails in Wisconsin, with a focus on Sora and Virginia Rail. Passenger Pigeon 61:277-289.

Rundle, W. D., and L. H. Fredrickson. 1981. Managing seasonally flooded impoundments for migrant rails and shorebirds. Wildlife Society Bulletin 9:80-87. 
Sayre, M. W., and W. D. Rundle. 1984. Comparison of habitat use by migrant Soras and Virginia Rails. Journal of Wildlife Management 48:599-605.

Schreiber, J. A. 1994. Structure of breeding-bird communities on natural and restored Iowa wetlands. M.S. thesis. Iowa State University, Ames, Iowa. 85 pages.

Schuster, J. E. 1998. Avian community composition and diversity in natural and restored central Iowa wetlands. M.S. thesis. Iowa State University, Ames, Iowa. 74 pages.

Shaw, S. A. 1887. Nesting of the Virginia Rail in New Hampshire. Ornithologist and Oologist 12:131-132.

Stabler, R. M., and N. J. Kitzmiller. 1971. A second Virginia Rail nesting for El Paso County, Colorado. Colorado Field Ornithologist 9:21.

Stewart, R. E. 1975. Breeding birds of North Dakota. Tri-College Center for Environmental Studies, Fargo, North Dakota. 295 pages.

Stewart, R. E., and H. A. Kantrud. 1965. Ecological studies of waterfowl populations in the prairie potholes of North Dakota. U.S. Fish and Wildlife Service, Bureau of Sport Fisheries and Wildlife. 1965 Progress Report. 14 pages.

Stewart, R. E., and H. A. Kantrud. 1971. Classification of natural ponds and lakes in the glaciated prairie region. Resource Publication 92. U.S. Fish and Wildlife Service, Bureau of Sport Fisheries and Wildlife. 57 pages.

Svedarsky, W. D. 1992. Biological inventory of a multi-purpose flood control impoundment in northwestern Minnesota and potentials for nongame and game bird management. Final Report. Northwest Agricultural Experiment Station, University of Minnesota, Crookston, Minnesota. 115 pages.

Tacha, R. W. 1975. A survey of rail populations in Kansas, with emphasis on Cheyenne Bottoms. M.S. thesis. Kansas State College, Fort Hays, Kansas. 54 pages.

Tanner, W. D. 1953. Ecology of the Virginia and King rails and the Sora in Clay County, Iowa. $\mathrm{Ph}$. D. dissertation. Iowa State College, Ames, Iowa. 154 pages.

Tanner, W. D., and G. O. Hendrickson. 1954. Ecology of the Virginia Rail in Clay County, Iowa. Iowa Bird Life 24:65-70.

Thompson, L. S. 1978. Transmission line wire strikes: mitigation through engineering design and habitat modification. Pages 27-52 in Impacts of transmission lines on birds in flight. Publication 78/48, U.S. Fish and Wildlife Service, Office of Biological Service, Washington, D.C. 
Tordoff, H. B., and R. M. Mengel. 1956. Studies of birds killed in nocturnal migration. University of Kansas, Publication of the Museum of Natural History 10:1-44. Lawrence, Kansas.

VanRees-Siewert, K. L. 1993. The influence of wetland age on bird and aquatic macroinvertebrate use of restored Iowa wetlands. M.S. thesis. Iowa State University, Ames, Iowa. 96 pages.

VanRees-Siewert, K. L., and J. J. Dinsmore. 1996. Influence of wetland age on bird use of restored wetlands in Iowa. Wetlands 16:577-582.

Vogel, J. A. 1999. Migration chronology and habitat use of webless migratory game birds in lower Missouri River floodplain wetlands. M.S. thesis. University of Missouri, Columbia, Missouri. 79 pages.

Walkinshaw, L. H. 1937. The Virginia Rail in Michigan. Auk 54:464-475.

Weller, M. W. 1999. Wetland birds: habitat resources and conservation implications. Cambridge University Press, Cambridge, New York. 271 pages.

Weller, M. W., and L. H. Fredrickson. 1973. Avian ecology of a managed glacial marsh. Living Bird 12:269-291.

Whitt, M. B., H. H. Prince, and R. R. Cox, Jr. 1999. Avian use of purple loosestrife dominated habitat relative to other vegetation types in a Lake Huron wetland complex. Wilson Bulletin 111:105-114.

Wood, H. B. 1937. Incubation period of Virginia Rail. Auk 54:535-536.

Zimmerman, J. L. 1977. Virginia Rail (Rallus limicola). Pages 46-56 in G. C. Sanderson, editor. Management of migratory shore and upland game birds in North America. International Association of Fish and Wildlife Agencies, Washington, D.C.

Zimmerman, J. L. 1984. Distribution, habitat, and status of the Sora and Virginia Rail in eastern Kansas. Journal of Field Ornithology 55:38-47. 


\section{Effects of Management Practices on Wetland Birds: Bibliography on Survey Methods for Virginia Rail}

Note: The most common survey method for Virginia Rails is to broadcast tape-recorded calls and listen for a rail to respond with its own call. Nests are located by wading through emergent vegetation in a zig-zag pattern.

In several articles, a passive sampling problem exists in the methodology of surveys. The incidence function may not be a reliable method for determining the "area sensitivity" of species if sampling effort increases with the size of the habitat block surveyed (Johnson, D. H. 2001. Habitat fragmentation effects on birds in grasslands and wetlands: a critique of our knowledge. Great Plains Research 11:211-231.). The incidence function is confounded with the regional density of a species. A rare species is less likely to be found in a small block, but is more likely to be found in a larger block because of increased sampling effort. Especially for uncommon or rare species, the greater the area of the habitat, the greater the probability of the species being present. This in itself, however, does not necessarily mean that the species is "area sensitive."

\section{Annotated articles}

Andrews, D. A. 1973. Habitat utilization by Sora, Virginia Rails and King Rails near southwestern Lake Erie. M.S. thesis. Ohio State University, Columbus, Ohio. 112 pages.

Presence and sizes of nesting populations, habitat use, daily movements, and external sex criteria of Soras, King Rails, and Virginia Rails were studied in managed (diked) wetlands during 1971 and 1972 in Ottawa and Sundusky counties, Ohio. Information on sexing criteria will not be presented in this summary. Sedge (Carex spp.), jewelweed (Impatiens capensis), crimsoneyed rosemallow (Hibiscus palustris), nodding beggartick (Bidens cernua), bluejoint (Calamagrostis canadensis), and cattail (Typha spp.) were the most abundant species of vegetation.

Rails were located by systematically searching wetlands on foot or by boat. Trained dogs were used to help flush rails. Rails were identified using binoculars and a spotting scope. Rails were captured and banded with U.S. Fish and Wildlife Service aluminum bands. Some were painted to allow for individual identification. Although various trap styles were tried, $2.5-\mathrm{cm}$ mesh poultry netting drift fences, and ramp-type walk-in traps were successful in capturing rails. Drift fences were from 15 to $120 \mathrm{~m}$ in length and were set up in a "V" shape leading toward the trap. Sometimes leads took the shape of the letters "N" or "W", making them effective in two directions. Leads were placed in paths cut in the vegetation using a scythe. Paths were from 0.3 to $1.8 \mathrm{~m}$ in width. The basic walk-in trap was constructed of galvanized, $2.54-\mathrm{cm}$ mesh, weldedwire fencing. Trap dimensions were $91 \mathrm{~cm}$ long, $30 \mathrm{~cm}$ wide, and $38 \mathrm{~cm}$ tall. A hatch was installed in the top of the trap to aid in removing the birds. Traps were used for both driving birds into the trap or as set and walk-in traps. Drives consisted of 1-15 drivers covering strips of vegetation up to $100 \mathrm{~m}$ in width. Mist netting was attempted, but was unsuccessful. Trapping was conducted from April through September during both years of the study. Areas were searched for rail nests on foot in a zig-zag pattern. Radio-harnesses were fitted to some of the rails and bird locations were tracked using radio-telemetry. 
Vegetation transects were $50 \mathrm{~m}$ apart at two study sites and $20 \mathrm{~m}$ apart on a third study site. A $1.8-\mathrm{m}$ staff that was $3.8 \mathrm{~cm}$ in diameter was placed vertically at 3.6-m intervals along each transect. Plant species touching or directly over the staff were recorded. Species frequency of occurrence was calculated. The area covered by various plant species was measured on cover maps with an acreage grid.

One hundred forty-eight Soras (78 adults and 70 juveniles) were captured in walk-in traps from May through September in 1971 and 1972. Two nests each of Sora and Virginia Rail were found.

Baird, K. E. 1974. A field study of the King, Sora and Virginia rails at Cheyenne Bottoms in west-central Kansas. M.S. thesis. Kansas State University, Manhattan, Kansas. 38 pages.

Census methods, habitat use, and abundance of King Rails, Soras, and Virginia Rails were studied at Cheyenne Bottoms in Barton County, Kansas during 1974. Dikes, roads, and canals had been constructed at this site to allow water-level control. The marsh was divided into five pools. About one-third of the marsh was drained each summer. The drained portion was seeded to Japanese millet (Echinochloa esculenta). The marsh was reflooded just before fall migration began. Water depths were increased throughout the winter months to attain a full marsh depth of $46 \mathrm{~cm}$.

Recorded calls were used to obtain an index to the number of rails (King Rail, Virginia Rail, and Sora). During April, survey routes were established by placing stakes at 100-m intervals in a zig-zag pattern across the study area. Surveys began 45 minutes before sunrise and were conducted weekly from mid-April through July. The author stopped at each stake to listen for calling rails for 3 minutes. Recorded calls then were played for an additional 3 minutes to solicit responses of rails. Species of rail, vegetation type, estimated water level, and whether the birds calling were singles or pairs were recorded.

Rails were captured for banding with walk-in ramp traps and poultry-netting drift fences. Traps were set in shallow water. Drift fences were $46 \mathrm{~cm}$ tall and extended out $45 \mathrm{~m}$ from the mouths of the traps. Drift fences were set in a variety of patterns, including straight-line, W-shaped, horseshoe-shaped, and Y-shaped. Drift fences were placed at right angles to the direction of rail travel (indicated by tracks) and to the position of the shoreline. Nineteen rails were killed by mink (Mustela vison) in the traps. Birds were banded using U.S. Fish and Wildlife Service bands. Rail nests were located using rope drags, intensive searches, and searches near pairs responding to taped calls. Vegetation transects were conducted in August. Transects were placed at $100-\mathrm{m}$ intervals throughout each study area. Wooden stakes $(2.5 \mathrm{~cm}$ by $5 \mathrm{~cm}$ by $1.8 \mathrm{~m})$ were placed at 30-m intervals along transects and plant species touching the stake were recorded. Points falling on open water and bare ground also were recorded.

No nests were found as a result of rope drags or intensive searches. Only one King Rail nest was found from searching areas from which pairs had responded. No other rail nests were found by these methods. Four nests (two King Rail nests, one Virginia Rail nest, and one Sora nest) were located incidental to surveys along established transects. 
Beule, J. D. 1979. Control and management of cattails in southeastern Wisconsin wetlands. Wisconsin Department of Natural Resources, Madison, Wisconsin. Technical Bulletin No. 112. 39 pages.

Birds were counted by two observers who simultaneously walked along different portions of a standardized 2-km transect route (width of transect not given). Four counts were conducted between 15 and 25 April and a second set of four counts were conducted between 15 and 25 May each year. Counts were not conducted during rain, snow, or winds $>24 \mathrm{kph}$. Nest searches were conducted once a year from mid-May to mid-June. Nest searching was conducted by four persons wading through an area of 1.5-1.8 $\mathrm{m}$ at 3-4-m intervals.

Brady, E. N. 1983. Birds on modified wetlands in eastern South Dakota. M.S. thesis. South Dakota State University, Brookings, South Dakota. 39 pages.

The value of dug brood complexes to non-waterfowl breeding bird species was evaluated. Dug brood complexes consisted of a system of channels, ponds, and spoil islands constructed on wetlands to provide deep, open water and upland nesting areas for waterfowl. This study examined the composition, density, and production of non-waterfowl breeding bird species. The study was conducted on seven wetland basins on Waterfowl Production Areas in Day and Clark counties in eastern South Dakota during the summers of 1981 and 1982. The mean wetland basin area of wetlands studied in Day County was 27 ha, whereas the mean wetland basin area studied in Clark County was17 ha.

The seven basins were each separated into two plots. One plot (modified plot) included the dug brood complex and a 50-m area surrounding the modification. The other plot (natural plot) was similar in area and vegetation to the modified plot and was located as far away from the modified plot as possible (but within the same wetland basin). Birds were surveyed using belt transects (40-m wide) during 15-26 June 1981 and 7-16 June 1982. Six transects of varying length (based on area of each wetland; mean transect length for 42 transects was $222 \mathrm{~m}$ ) were surveyed in each of the seven wetlands, three in the modified plot and three in the natural plot. Transects in the modified plots of each wetland were equal in length to the transects conducted in natural plots within the same wetlands. All birds heard or observed within the transects were recorded. Surveys were conducted between 0600 and $0830 \mathrm{~h}$ and between 1800 and $2130 \mathrm{~h}$. Surveys were not done when winds were $>25 \mathrm{kph}$ or in rain. Taped recordings of Virginia Rail, Sora, Yellow Rail, and King Rail were used to detect these species in 1982. Recorded calls of these species were played from stations (how many per wetland was not specified) that were at least $60 \mathrm{~m}$ apart. At each station, calls of each species were played in the following manner: three groups of three rail calls for a total of nine calls, followed by a listening period of 1 minute between calls. The number of rails responding to calls was recorded at each station. Nest searches were conducted on 42 islands in the modified plot (nest-searching method was not specified). Species, clutch size, and distance to the shoreline were recorded for each nest.

Counts of bird species were based on the number of indicated pairs (Stewart, R. E., and H. A. Kantrud. 1972. Population estimates of breeding birds in North Dakota. Auk 89:766-788.). The majority of indicated pairs were observed as segregated pairs or as territorial males. However, segregated pairs and lone females of Wilson's Phalarope were recorded as indicated pairs. In species where sex could not be determined, such as Black Tern, the number 
of indicated pairs was calculated as the number of individuals counted divided by two. Rallidae species were recorded as the number of audibly responding rails per hectare.

A total of 38 species of birds were recorded on the transects. The most abundant species in modified plots in 1981 in decreasing order were Red-winged Blackbird, Common Yellowthroat, and Song Sparrow. The most abundant species in natural plots in decreasing order were Red-winged Blackbird, Marsh Wren, and Common Yellowthroat. In 1982, the most abundant species occurring in both natural and modified plots were Red-winged Blackbird, Marsh Wren, and Common Yellowthroat. The mean densities for wetland birds in modified plots were 14.39 pairs/ha, compared to 17.35 pairs/ha in natural plots. Mean species diversity (Shannon-Weaver) values for modified and natural plots were 1.68 and 1.54, respectively. Species richness values averaged 4.69 species and 4.31 species in modified and natural plots, respectively. Mean evenness values for modified and natural plots were 0.95 and 0.89 , respectively. No significant differences in species diversity, species richness, and evenness were found between the two treatments. Significant differences in these variables were found among the seven wetland basins. Basins with the highest diversity and species richness had vegetation approaching hemi-marsh conditions.

Brown, M., and J. J. Dinsmore. 1986. Implications of marsh size and isolation for marsh bird management. Journal of Wildlife Management 50:392-397.

The influence of marsh area and isolation on species richness of marsh birds was examined for 30 marshes throughout northwestern and northcentral Iowa from 1983-1984. Marshes were either seasonal or semipermanent, ranging from 0.2 to 182 ha in size. Avian censuses were conducted using $18 \mathrm{~m}$ fixed-radius circular plots centered in the emergent vegetation zone. Taped recordings of calls were used to detect secretive birds. Nest-searching was conducted within $13 \mathrm{~m}$ of the circular plot. Twelve variables were measured to determine the degree of marsh isolation: distance to nearest marsh $<5$ ha in size; distance to nearest marsh 5-20 ha in size; distance to nearest marsh $>20$ ha in size; number of marshes within $1 \mathrm{~km}$; number of marshes within $3 \mathrm{~km}$; number of marshes within $5 \mathrm{~km}$; total area of marshland within 1,3 , and $5 \mathrm{~km}$; and total area of lakes within 1, 3, and $5 \mathrm{~km}$.

Twenty-five bird species were recorded. Of the 12 isolation variables, area of marshland within $5 \mathrm{~km}$ of each site was the only one to show a significant relationship with species richness, and then only in 1983.

Conway, C. J. 1990. Seasonal changes in movements and habitat use by three sympatric species of rails. M.S. thesis. University of Wyoming, Laramie, Wyoming. 58 pages.

Seasonal variation in habitat use, movement, and area requirements of the Yuma Clapper Rail, Virginia Rail, and Sora were studied in the Mittry Lake Wildlife Management Area in southwestern Arizona (years of study were 1985-1987, given in Conway, C. J., Eddleman W. R., and S. H. Anderson. 1994. Nesting success and survival of Virginia Rails and Soras. Wilson Bulletin 106:466-473.). The study was conducted on a 122-ha section of wetland on the northern edge of the lake. Rails were captured using walk-in drop-door traps with drift fences made from nylon-mesh netting stapled to 2-m wooden lathe stakes. Traps consisted of 2.5-cm 
mesh wire (dimensions not given). Taped recordings of female solicitation calls were played to lure males into traps (no further details were given). Rails were banded using U.S. Fish and Wildlife Service aluminum bands and fitted with either a harness-type radio-transmitter (for Clapper Rails) or a radio-transmitter glued to the rail's back (for Virginia Rails and Soras). Radio-transmitters averaged $10 \mathrm{~g}$ for the larger units used on Clapper Rails and $3 \mathrm{~g}$ for units used on Virginia and Sora Rails. Locations of radio-marked rails were triangulated using four fixedsite, 12-element, null-peak telemetry stations placed on the eastern shore of the wetland. Locations were obtained from at least two simultaneous azimuths taken from telemetry stations. Rail locations were monitored for 1-6 h during the day; tracking times were stratified to incorporate each period of diurnal activity (exact hours of diurnal activity not defined).

Habitat measurements were recorded at the end of each month (all months of the year were sampled) at 4-10 random $1 / 4 \mathrm{~m}^{2}$ plots in heavy-use sites. The number of random plots sampled depended upon the number of telemetry locations that occurred at each heavy-use site that month. Heavy-use sites were areas $20 \times 20 \mathrm{~m}$ that contained at least four telemetry locations for one rail in one month. In addition, each month, vegetation from 30 randomly selected points within the wetland was sampled to determine habitat availability. Only plots occurring in vegetative zones that were used in proportion to or in excess to their availability were sampled so that microhabitat preferences could be determined. Habitat measurements recorded were percent emergent basal cover, percent residual basal cover, percent bare ground interspersion (not defined), percent water interspersion (not defined), water depth, mean height of emergent vegetation, distance to nearest edge (types of edges not defined), distance to nearest open water, distance to upland, distance to nearest dry ground (difference between upland and nearest dry ground not specified), total stem density (not defined), and percent overhead cover.

The number of radio-transmitters attached to Clapper Rails, Soras, and Virginia Rails were 42, 34, and 42, respectively. The number of locations recorded for Clapper Rails, Soras, and Virginia Rails were 8000, 1192, and 3608, respectively. The number of daily movements recorded for Clapper Rails, Soras, and Virginia Rails were 837, 198, and 615, respectively. Habitat characteristics were recorded on 404 plots on 96 heavy-use sites for Clapper Rails, 253 plots on 59 heavy-use sites for Soras, and 416 plots on 100 heavy-use sites for Virginia Rails.

Crowley, S. K. 1994. Habitat use and population monitoring of secretive waterbirds in Massachusetts. M.S. Thesis. University of Massachusetts Amherst, Amherst, Massachusetts. 108 pages.

This thesis was composed of five chapters: 1) Introduction, 2) Status of selected waterbirds in Massachusetts, 3) Habitat models for six species of waterbirds in Massachusetts, 4) Fine scale habitat selection of Soras, Virginia Rails, and Marsh Wrens during breeding season in Massachusetts, and 5) Playback calls fail to increase detection rates of American Bitterns and Green-backed Herons. Target species included Pied-billed Grebes, American Bitterns, Least Bitterns, Great Blue Herons, Green-backed Herons, Virginia Rails, Soras, Marsh Wrens, King Rails, and Common Moorhens. Only information contained in chapters three and four are summarized below.

Chapter 3: Habitat models for six species of waterbirds in Massachusetts

Habitat selection of American Bitterns, Great Blue Herons, Green-backed Herons, 
Virginia Rails, Soras, and Marsh Wrens was studied in Massachusetts from 1991 to 1993.

Presence or absence of target species was determined at 117 wetlands throughout Massachusetts. Wetlands were freshwater palustrine, riverine, or lacustrine and contained $\geq 0.1$ ha of emergent vegetation. Incidental observations reported by birders were used as evidence of presence of target species at an additional 26 wetlands, for a total of 143 wetlands. Wetland sizes ranged from 0.2-190 ha. One to 10 survey stations were established per wetland. Stations were $100 \mathrm{~m}$ apart. Stations were located along the edge of the wetland, or were conducted from a canoe along navigable channels at the interface of open water/aquatic bed and emergent vegetation. Each year, wetlands were surveyed three times from 1 May to 7 July from $1 / 2 \mathrm{~h}$ before sunrise to $4 \frac{1}{2} \mathrm{~h}$ after sunrise on days with little or no precipitation and low ( $\left.<25 \mathrm{kph}\right)$ wind speeds. A 3minute passive listening period was followed by a broadcast of tape-recorded calls of Pied-billed Grebe, American Bittern, Least Bittern, Green-backed Heron, Virginia Rail, Sora, King Rail, and Common Moorhen. Calls were played at 85-95 db $1 \mathrm{~m}$ from the source. Recordings were from the Library of Natural Sounds, Cornell Laboratory of Ornithology. Calls of Pied-billed Grebe were broadcast from every third station and American Bittern calls were broadcast from every second station because these species could be detected over greater distances than others (Gibbs, J. P., and S. M. Melvin. 1993. Call-response surveys for monitoring breeding waterbirds. Journal of Wildlife Management 57:27-34.). Area of plant species, open water-vegetation interspersion, interspersion of vegetative types, area of non-forested wetlands within $3 \mathrm{~km}$ of the focal wetland, number of human habitations within $100 \mathrm{~m}$ of the edge of the wetland divided by the perimeter length (density of nearby houses), number of human habitations within $500 \mathrm{~m}$ of the wetland edge (nearby urbanization), soil type, water conductance, and water $\mathrm{pH}$ were measured at each wetland. National Wetlands Inventory maps were used to determine juxtaposition of wetlands. Area of non-forested wetlands within $3 \mathrm{~km}$ of the focal wetland was determined from maps the U.S. Fish and Wildlife Service had measured with a digital planimeter. Number of habitations within $100 \mathrm{~m}$ of the focal wetland was tallied during field visits and the number of habitations within $500 \mathrm{~m}$ was measured from U.S. Geological Survey topographic maps. Number of habitations was confirmed during field visits. Dominant soil types were determined from county soil survey maps.

Field maps of wetland edges and boundaries of vegetation types were traced from 2.54 cm:198 m black and white aerial photographs obtained from county U. S. Department of Agriculture Agricultural Stabilization and Conservation Service offices. Water samples were collected from $1 / 2 \mathrm{~m}$ below the surface of the water near the outlet of the wetland during August or September, and analyzed using an Orion Research Model 211 pH meter and a YSI Model 233 conductivity meter. A digital planimeter was used to measure areas of each vegetation type on maps.

Chapter 4: Fine scale habitat selection of Soras, Virginia Rails, and Marsh Wrens during breeding season in Massachusetts

Fine-scale habitat use by Soras, Virginia Rails, and Marsh Wrens was studied in wetlands in Massachusetts in 1991 and 1992. Percent cover of eight cover types (cattail [Typha], phragmites, fine-leafed emergents, purple loosestrife [Lythrum salicaria], Decodon, pickerelweed [Pontederia cordata]/arrowhead [Sagittaria], scrub, and shrub) and water depth were measured within a 2-m radius of individual locations of waterbirds.

Soras used deeper water (mean of $20.4 \mathrm{~cm}$ for 34 sites) than either Virginia Rails (mean of 13.3 for 230 sites) or Marsh Wrens (mean of $14.1 \mathrm{~cm}$ for 152 sites). Virginia Rails used more 
fine-leaved emergents (mean of 31.3\% cover for 230 sites) and scrub (mean of 3.2\% for 230 sites) than did Marsh Wren (mean of 26.3\% fine-leaved emergents and 1.5\% scrub at 152 sites). Soras used amounts of fine-leaved emergents and scrub intermediate between, but significantly different from, Virginia Rails and Marsh Wrens. Percent cover of purple loosestrife averaged $<5 \%$ at sites occupied by Virginia Rail and Marsh Wren, and no Soras were observed in purple loosestrife.

Daub, B. C. 1993. Effects of marsh area and characteristics on avian diversity and nesting success. M.S. thesis. University of Michigan, Ann Arbor, Michigan. 37 pages.

Daub examined the relationship between marsh area, species richness, and nesting success in 20 marshes located near Minnedosa, Manitoba, from 1991-1992. All marshes were semipermanent or permanent, and ranged in size from 0.1-19.3 ha. Avian censuses were conducted along the perimeter of marshes by placing a randomly chosen, $100 \mathrm{~m}$ x $15 \mathrm{~m}$ transect, along which nest-searching also occurred. The $15 \mathrm{~m}$ portion of the transect included $5 \mathrm{~m}$ of emergent vegetation and $10 \mathrm{~m}$ of open water. Each transect was walked for $45 \mathrm{~min}$. Each marsh was surveyed three times during the breeding season, about every two weeks. Playback calls were used to elicit responses from American Bittern, Virginia Rail, Yellow Rail, and Sora at the beginning, middle, and end of each transect during every survey. Nesting success was determined using the Mayfield method. Measured marsh characteristics were water depth, vegetative composition (line-intercept technique), and width of vegetation growing in standing water.

Twenty-eight bird species were recorded, and 12 species were found nesting. Number of nesting species showed no relationship to marsh area or other measured marsh characteristics (water depth, vegetative composition, and width of vegetation growing in standing water). A significant positive relationship existed between marsh area and species richness. Other marsh characteristics were unrelated to species diversity. A list of area dependent, area independent, and possibly area dependent species was given.

Fairbairn, S. E., and J. J. Dinsmore. 2001. Local and landscape-level influences on wetland bird communities of the prairie pothole region of Iowa, USA. Wetlands 21:41-47.

Bird species richness and species' densities were measured and related to 11 habitat variables within wetlands and to the area of wetlands in the surrounding landscape in the Prairie Pothole Region of northern Iowa during 1998. Seventeen study sites in central, northcentral, and northwestern Iowa ranging in size from 44 to 144 ha and comprising 4 to 15 wetlands each were surveyed once between mid-May and the first week of July 1998 between sunrise and 4 hours after sunrise. Surveys did not take place during rain or high (not defined) winds. Each singing male was considered part of a pair and was counted as two birds. Surveys began with scanning the open water from a distance and then bird counts were conducted at a set number of points (placement criteria not reported). One survey point was established in wetlands $<0.4 \mathrm{ha}$, two in wetlands 0.4-1.0 ha, three in 1-2 ha wetlands and one additional point was established for each additional 1.6 ha of wetland. Passive listening and responses to taped calls were used to detect secretive species. Surveys lasted 6 minutes: the first 2 minutes was passive listening, taped calls 
were played during the middle 2 minutes, and the final 2 minutes was passive listening. The sequence and number of calls broadcast for each species were not specified. The emergent vegetation zone was waded as researchers proceeded from point to point and all birds seen or heard were counted. Surveys of wetland complexes took from 1 to 4 days to complete. The total number of individuals of each species was divided by the wetland area in the complex to obtain density. Species were included in the analysis if young, eggs, or a nest was observed or if breeding behavior was noted and a considerable amount of suitable nesting habitat was available in the wetland for that species.

Twenty-eight bird species nested in the study sites. Total wetland area within a complex and the percentage of wetland area within a complex covered with emergent vegetation explained $>60 \%$ of the variation in species richness overall. The total area of wetland habitat in the surrounding $3 \mathrm{~km}$ of complexes was also a significant predictor of species richness.

Gibbs, J. P., J. R. Longcore, D. G. McAuley, and J. K. Ringleman. 1991. Use of wetland habitats by selected nongame birds in Maine. U.S. Fish and Wildlife Service, Fish and Wildlife Research Report No. 9. 57 pages.

Results of waterbird surveys of 87 palustrine and lacustrine wetlands in central and eastern Maine were reported for the period 1977-1985. Birds were surveyed from elevated platforms concealed at wetland margins for 2-3-h periods from $0.5 \mathrm{~h}$ before sunrise or $1.5 \mathrm{~h}$ before sunset and continuing for $2 \mathrm{~h}$. Wetlands were visited $\geq 4$ times per breeding season, April through August. The number of observers surveying the wetland was dependent on wetland size, with larger (not defined) wetlands having up to eight persons simultaneously surveying the wetland. Effects of wetland area on occurrence were confounded by a passive sampling problem. The number of individuals and the number of times each species was observed or heard was recorded. Variables were measured over the entire wetland and included area (ha), shoreline development (linear distance around the perimeter of surface water [m]), percent and area of open water, percent and area of submergent and floating-leaved vegetation, percent and area of emergent vegetation, percent and area of ericaceous vegetation (e.g., leatherleaf [Chamaedaphne] and laurel [Kalmia]), percent and area of alder (Alnus)-willow (Salix) vegetation, percent and area of flooded timber, a surface water irregularity index (ratio of surface water perimeter to the perimeter of a circle with an area equal to that of the surface water), lifeform diversity index (not clearly defined), interwetland distance (m), and distance to road (m). Birds flying over the wetland were not included in analyses. Data from the following species were analyzed: Common Loon, Pied-billed Grebe, Double-crested Cormorant, American Bittern, Great Blue Heron, Green-backed Heron, Osprey, Bald Eagle, Northern Harrier, Virginia Rail, Sora, Spotted Sandpiper, Common Snipe, Herring Gull, and Belted Kingfisher.

Overall, a greater number of species used wetlands with intermediate amounts (33-66\%) of vegetation cover than wetlands with either more $(>66 \%)$ or less $(<33 \%)$ emergent cover. Individual species' accounts were included in the results.

Gibbs, J. P., and S. M. Melvin. 1993. Call-response surveys for monitoring breeding waterbirds. Journal of Wildlife Management 57:27-34. 
Tape-recorded calls of Pied-billed Grebe, American Bittern, Least Bittern, Virginia Rail, and Sora were played at 60 wetlands in Maine in 1989 and 1990 in an effort to develop a survey method capable of monitoring regional population trends for these species. Other objectives were to determine the minimum number of visits to a wetland needed to determine species presence, to examine whether conspecific calls increased the delectability of each species, estimate the range of distances over which each species was detected, examine types and timing of responses to tape-recorded calls, determine the effects of environmental variables on response rate of each species, and to design standardized call-response surveys to monitor these waterbird species. Wetlands were surveyed between 1 May and 15 July 1989 and 1990. Of 60 wetlands surveyed, 36 were palustrine, 16 lacustrine, and 8 riverine (classification by Cowardin, L. M., V. Carter, F. C. Golet, and E. T. LaRoe. 1979. Classification of wetlands and deep water habitats of the United States. U.S. Fish and Wildlife Service. Office of Biological Services, Washington, D.C., USA. FWS/OBS-79/31.). Emergent vegetation areas within wetlands ranged from 0.1 to 125 ha. Each wetland was surveyed three times and surveys were conducted between 30 minutes before sunrise to $4 \mathrm{~h}$ after sunrise. Each survey began with the observer standing at the wetland margin for 15 minutes and recording all waterbirds seen or heard. Taped recordings of each species' call were then played at $0.75 \mathrm{~m}$ above ground at fixed survey stations from a portable cassette player with a maximum sound pressure of $80 \mathrm{db} 1 \mathrm{~m}$ from the source. Most ( $>95 \%$ ) stations were surveyed from a canoe and the remaining on foot. Survey stations were located throughout the wetland such that there was one station per 5 ha of wetland. Researchers alternated among three tapes consisting of species' calls in random order on a daily basis. Tapes consisted of about 50 seconds of male territorial vocalizations interspersed with 10 seconds of silence. The calls of the following species were broadcast: Pied-billed Grebe, Least Bittern, American Bittern, Sora, Virginia Rail, Green-backed Heron, American Coot, and Common Moorhen. The following variables were recorded: estimated distance to each response, species being played during each response, type of contact (aural, visual, both), date, time of day, wind speed (0-4, 5-9, 10-19, and $\geq 20 \mathrm{kph}$ ), precipitation (none, drizzle, rain), and cloud cover ( $<33 \%$, $33-66 \%$, and $>66 \%$ ). Detection rates of all species improved with the use of recorded calls compared to passive observation for 15 minutes. Mean detection distances varied significantly with species.

Mean detection distance for 217 Virginia Rail responses was $77.2 \mathrm{~m}$; most responses were within $50 \mathrm{~m}$ of the observer. Of 217 responses, 96\% were aural and 4\% were both. Of 215 responses, 58\% were during conspecific calls and $42 \%$ were during interspecific calls.

Probability of response was 0.16 in early May, increased to 0.25 in late May, decreased again to 0.2 in early to mid-June, and increased again to 0.3 in early July. Probability of response was similar throughout the morning. Probability of response significantly increased under cloud cover $\geq 33 \%$.

\section{Survey suggestions:}

-Survey American Bitterns during May and prior to $0800 \mathrm{~h}$.

-Survey for Least Bitterns in late May and throughout June.

-Survey secretive waterbirds in a region, state, or physiographic stratum annually using broadcast vocalizations at a stratified random sample of wetlands. Stratify sampling effort among species-rich wetlands; small, low quality wetlands; and wetlands where the species were present historically. 
Glahn, J. F. 1974. Study of breeding rails with recorded calls in north-central Colorado. Wilson Bulletin 88:206-214.

Tape-recorded calls were used to survey Virginia Rails and Soras in northcentral Colorado in 1972. The study also aimed to determine the distribution of nesting territories and breeding densities of Virginia Rails and Soras. A 30-m interval grid system was created in each wetland with flagging. Gridded maps using a 1:1200 scale were then made from these survey measurements. Locations where rails responded to taped calls were marked on the gridded maps. During each survey, standard transect lines $60 \mathrm{~m}$ apart were traversed in a zig-zag pattern through the wetland. A 5-minute tape consisting of 10 calls of each species was broadcast at points $60 \mathrm{~m}$ apart along the transect. Calls were played on a Uher Model 4000 tape recorder with a sound pressure level of 93-96 db $1 \mathrm{~m}$ from the source. One half of the wetland areas were surveyed in the first $3 \mathrm{~h}$ after sunrise, and the remaining wetland areas were surveyed $3 \mathrm{~h}$ before sunset on the same day. Wetlands were surveyed alternately in the morning and evening. Surveys were not conducted when winds were $>24 \mathrm{kph}$. Ten semiweekly surveys were conducted between 26 April and 28 May, with at least $2 \mathrm{~d}$ in between surveys. The number of rails responding 5 minutes each before, during, and after taped calls were played was recorded. The distance at which rails first responded and the number of calls needed to elicit a response was recorded. Intensive nest searches were conducted from mid-May to mid-July in areas where rails were heard calling.

The estimated number of breeding pairs was 18 pairs of Virginia Rails and six pairs of Soras (based on maps of calling birds and a total of 14 nests found). Playback of taped calls significantly increased the rate and frequency of calling rails. During 50 5-minute trials, the frequency of calls increased from 31 prior to playback to 134 during playback. The number of taped calls needed to elicit a response ranged from 1 to 10 but $79 \%$ responded during the first five calls and 35\% responded after the first call. The maximum distance a rail was detected was $80 \mathrm{~m}$, and $90 \%$ of responding rails were within $60 \mathrm{~m}$ of the speaker. Virginia Rails and Soras responded equally well to each other's calls as to their own calls. Recordings of duet calls (both male and female calling simultaneously) elicited a better response than single calls alone. Virginia Rail response peaked in late April-early May and in late May. Sora response peaked in early May.

Graber, R. R., and J. W. Graber. 1963. A comparative study of bird populations in Illinois, 1906-1909 and 1956-1958. Illinois Natural History Survey Bulletin 28:383-528.

Information on the habitat use, distribution, and abundance of the birds of Illinois were presented. The study compared a bird survey conducted from 1956-1958 to the original study done by Gross and Ray in 1906-1909. The census method required two observers to record birds within transects 100 yards wide. Three zones were examined: northern, central, and southern Illinois. Habitats censused were plowed fields, cropland (soybeans, oat, wheat), pasture, idle grassland, idle, mixed and pure stands of hay, marshland, shrubby areas, orchards, forests, and residential areas. Population densities for species in summer and winter for each habitat and for each zone are given. 
Graetz, J. L., S. W. Matteson, J. Skoloda, and C. Ribic. 1997. Status and distribution of marsh and sedge meadow birds at Horicon, Necedah, and Trempealeau national wildlife refuges in 1995. Passenger Pigeon 59: 119-130.

A baseline inventory of wetland and wetland margin birds was compiled in 1995 for three refuges (Horicon, Necedah, and Trempealeau national wildlife refuges) in Wisconsin. Goals of the inventory were to estimate relative abundance and determine densities and species richness, as well as to make recommendations for a long-term monitoring program. Major habitat types were delineated and vegetation and bird surveys were conducted within homogeneous areas of cattail (Typha spp.), bulrush (Schoenoplectus spp.), sedge (Carex spp.) meadow, and mixed stands of these. Points were selected within areas easily accessible by foot, boat, or road. Ten random locations between 50 and $100 \mathrm{~m}$ from refuge roads were generated such that they were at least $200 \mathrm{~m}$ apart. Birds were surveyed using variable circular-plot methods and by broadcasting taped calls. Each point was surveyed between 0600 and $1000 \mathrm{~h}$ once during late May and again in early June. All birds detected aurally or visually were recorded and the distance to each was estimated upon detection. After the point count, taped calls of American Bittern, Least Bittern, Black Rail, Yellow Rail, Sora, Virginia Rail, and King Rail were played with a $10 \mathrm{~s}$ interval between each species' call. Observers estimated distances to responding individuals. Responses to taped calls also were recorded during 2100-2400 hrs at a sample of the ten random points at each sampling location.

Fifty-five species were detected during surveys. More Virginia Rails were detected in 10 surveys in cattail (10-19 individuals), than in the same number of surveys in sedge (7-8), mixed (4-13), or bulrush (0) stands.

Griese, H. J. 1977. Status and habitat utilization of rails in Colorado. M.S. thesis. Colorado State University, Fort Collins, Colorado. 67 pages.

Distribution, breeding densities, habitat, and migration dates were studied for Virginia Rails and Soras in Colorado during 1975-1976. One study area was selected to represent typical wetlands in each of four main regions in Colorado. The four main study areas were 1) Lower Latham Reservoir (13.1 ha), Weld County, northcentral Colorado; 2) John Martin Reservoir (14.5 ha), Bent County, southeastern Colorado; 3) Monte Vista National Wildlife Refuge (14.3 ha), Rio Grande County, southcentral Colorado; and 4) Gary Ranch (6.1 ha) and Milk Creek (4.8 ha), Routte and Moffat counties, respectively, northwestern Colorado. Mean water depths at all study areas ranged from 2-10 cm, except on the Gary Ranch study area, which averaged $31 \mathrm{~cm}$ and $20 \mathrm{~cm}$ for 1975 and 1976, respectively.

Study sites were surveyed using playbacks of tape-recorded calls of rails. Surveys were conducted at sunrise or sunset May through October 1975 and April through October 1976. Twelve to 26 surveys stations were established 80-130 m apart at each study area. Sound pressure of recordings was 80.5-96 db $1 \mathrm{~m}$ from the source. Six to 15 calls of each species were played in a series of alternating groups with three repetitions of each species and 1 minute of silence in between groups. Black, King, and Yellow rail calls were occasionally played. Locations of responding rails were plotted on field maps. The breeding index was described as responding rails per ha and was calculated by averaging results from surveys immediately 
following peak concentrations of birds through early July. A second index was derived from spot-mapping and was defined as the number of territories per ha. Distribution of rails was obtained through numerous surveys of wetlands while traveling among study areas (method of wetland selection not given), responses to questionnaires (sent to Colorado Division of Wildlife field personnel), and previously published records. Surveys conducted at wetlands encountered while traveling among study areas included tape-recorded playbacks of 12-24 calls at 1-7 stations. If playback surveys failed to reveal rails, flushing transects (not described), track searches (not described), and trapping were used. Funnel entry box traps measuring 25 by 31 by $61 \mathrm{~cm}$ and made from 1.4-cm hardware cloth were used for trapping. Drift fences leading up to traps were 3-33 m long, 30-45 cm tall, and constructed from 2.5-cm mesh poultry netting. Rails were banded with U.S. Fish and Wildlife Service size 3 aluminum bands.

Field maps of wetlands were derived from U.S. Geological Survey 7.5-minute topographic maps and aerial photographs. Wetland size and percent composition of major vegetation types (specific list of major vegetation types not given) were calculated from field maps using a planimeter. Water-level fluctuations were recorded during surveys. Nest searching methods were not specified. Twenty-five nests of Sora and Virginia Rail (combined) were located.

Hanowski, J. M., G. J. Niemi, A. R. Lima, and R. R. Regal. 1997. Response of breeding birds to mosquito control treatments of wetlands. Wetlands 17:485-492.

The effects of two mosquito (Culicidae) control measures were studied in southcentral Minnesota in 1988, 1990, and 1991-1993. The two mosquito larvicides used were methoprene (trade name Altosid ${ }^{*}$ ) and Bacillus thuringiensis israelensis (Bti; applied as Vectobac-G ${ }^{*}$ granules). These two methods were commonly used to control adult mosquito emergence and were considered safe in terms of toxicity (rat [Rattus] oral LD50 for methoprene was $>34,000$ $\mathrm{mg} / \mathrm{kg}$ ). An indirect effect of the treatments to wetland bird species was a reduction of invertebrate prey items. The study objective was to determine if mosquito control treatments affected bird species density and/or composition by altering food availability. Twenty-seven wetlands were selected for study that met the following criteria: (1) had not been previously treated for mosquitoes, (2) were $>1$ ha in size, (3) contained cattails (Typha spp.) or shrub vegetation suitable for Red-winged Blackbirds; and (4) were not part of or near road rights-ofway. Wetlands were permanent, type $3(n=14)$ or $4(n=9)$ wetlands (Cowardin, L. M., V. Carter, F. C. Golet, and E. T. LaRoe. 1979. Classification of wetlands and deep water habitats of the United States. U.S. Fish and Wildlife Service. Office of Biological Services, Washington, D.C., USA. FWS/OBS-79/31.). Bti and methoprene were applied to wetlands by helicopter six times during spring and summer, each year from 1991 to 1993. Rates of application for Bti and methoprene were 1.0-1.8 kg/ha. The initial application was made when mosquito larvae were first detected. Subsequent applications were made after each $1.5 \mathrm{~cm}$ or greater rainfall event or after three weeks, whichever came first.

The point count method was used (Reynolds, R. T., J. M. Scott, and R. A. Nussbaum.

\footnotetext{
* References to chemical trade names does not imply endorsement of commercial products by the Federal Government.
} 
1980. A variable-circular plot method for estimating bird numbers. Condor 82:309-313.). The number of points sampled per site corresponded to the area of each wetland. Adjacent points within a wetland were a minimum of $225 \mathrm{~m}$ apart and $125 \mathrm{~m}$ from the wetland edge. Birds were counted at each point for 10 minutes followed by a playback of the songs of the Virginia Rail and Sora that lasted 2 minutes. Birds were counted within a $100 \mathrm{~m}$ radius of the census point and in most cases the $100 \mathrm{~m}$ radius was entirely within the wetland. On a few smaller sites only the birds within the wetland were counted. Counts were conducted by trained observers and were conducted only in good weather.

Cover types and watershed size were determined using digitized topographic maps. In 1991, habitats within the wetlands were open water (average of 35\% across all sites), live cattails (19\%), sedge (Carex spp.; 14\%), and grass (11\%). Watershed size ranged from 4 to 8623 ha and wetland size ranged from 2 to 53 ha. Water depths were measured under Red-winged Blackbird nests to document the overall pattern of water depth from 1988 to 1993, but these measurements were not presented in this paper.

Only four bird species showed significant differences in abundance between control and treatment wetlands, and these differences were not consistent among years. Significant differences in abundance were not found, or differences were too inconsistent to make conclusions, for Killdeer, Barn Swallow, Cliff Swallow, Tree Swallow, Swamp Sparrow, Redwinged Blackbird, Yellow-headed Blackbird, Common Grackle, and American Goldfinch. The authors concluded that birds were not affected by mosquito control treatments in the first three years of treatment. Differences in moisture regimes during the study also may have had confounding effects. The authors stated that a possible reason for the lack of treatment effect in the study is that individual species abundance in wetlands vary annually and this change is greater than would be expected from mosquito control treatments.

Hartman, M. R. 1994. Avian use of restored and natural wetlands in northcentral Indiana. M.S. thesis. Purdue University, West Lafayette, Indiana. 98 pages.

Differences in avian community composition between natural and restored wetlands were studied in Indiana during 1993 and 1994. In 1993, 13 restored and four natural wetlands were studied. In 1994, 13 restored and three natural wetlands were studied. Objectives of the study were to (1) determine avian use of recently (3-5 yr since restoration) restored and natural wetlands; (2) determine specific abiotic and biotic variables that were influencing habitat use; (3) develop predictive models of bird species diversity (BSD), bird species richness (BSR), and breeding bird species richness (BBSR) based on abiotic and biotic variables; and (4) determine if different bird guilds share similar habitats.

Bird surveys were conducted bi-weekly from late April to early August in 1993 and from early May to mid-July in 1994. The author also revisited five wetlands in 1994 that were first surveyed in 1993. Surveys were conducted 3 hours after sunrise and 3 hours prior to sunset. Surveys were not conducted in inclement weather. Before entering the wetland, waterfowl were surveyed using a spotting scope. Taped songs of Sora, Virginia Rail, Pied-billed Grebe, American Bittern, and Least Bittern were played at a minimum of one location per wetland (detailed methods of playback calls not given). The perimeter of each wetland was walked and all birds seen or heard within a 10-m radius of the border (not defined) were recorded. Nest searches (precise method not specified) also were conducted after the survey was completed. 
Vegetation sampling was conducted in May, mid-June, and mid-July in 1993 and in early May in 1994. Two permanent transects were established in each wetland and three habitat categories were delineated: open water, border, and upland. The transects crossed at a central point in the wetland and they extended $10 \mathrm{~m}$ beyond the water line. Five sampling sites were established in each habitat category. At each point, species of emergent vegetation was identified, measured (height), and the number of stems were counted within a $0.25-\mathrm{m}^{2}$ area. An estimate of the coverage of floating plants and a measurement of water depth also were conducted. Emergent, submergent, and floating-leaved plants were collected using a 10.16-cm diameter PVC pipe made into a core sampler. Plant samples were identified, dried, and weighed. Upland plants were sampled by counting the number of stems within a $0.25 \mathrm{~m}^{2}$ area and classifying them as grasses, sedges (Carex spp.), or forbs.

Macroinvertebrate sampling was conducted in late May and early July, 1993, and in late May, 1994. Sampling points were the same locations as those used for vegetation, except for upland sites (determination of the location of sampling points in upland sites was not specified). Two methods were used for sampling invertebrates: a sweep net was passed just below the water surface for a length of $1 \mathrm{~m}$, and a benthic core sample of the top $5 \mathrm{~cm}$ was taken using the same tube used for the vegetation sampling. Macroinvertebrates were identified, counted, dried, and weighed.

Conductivity, salinity, and water temperature readings were taken at the central point of each wetland at the time of vegetation sampling.

Aerial photographs were used to assess the percent emergent vegetation, wetland size, and distance to nearest body of water.

Eighty-four bird species were found on all wetlands. Twenty-seven species nested on the study wetlands. There was no significant difference in BSD, BSR, or BBSR between restored and natural wetlands in either year or between years. No significant difference existed between BSD, BSR, or BBSR and restored wetland age. Mean BSD was significantly higher in 1993 than in 1994. Area and inter-wetland distance were significant predictors of BSR and BSD in 1993, but inter-wetland distance was not a predictor for BSR in 1994 and neither variables were significant predictors of BSD in 1994. Area was a significant predictor of BBSR.

Hemesath, L. M. 1991. Species richness and nest productivity of marsh birds on restored prairie potholes in northern Iowa. M.S. thesis. Iowa State University, Ames, Iowa. 87 pages.

The use of restored wetlands by bird species was studied in northern Iowa in 1989 and 1990. The objectives of the study were to determine the effect of wetland area on bird species richness and to determine which bird species would colonize restored wetlands in the first three years after restoration. Sixteen and 17 restored wetlands were studied in 1989 and 1990, respectively. Restored wetlands were $1-3$ yr old and ranged in size from 0.8 to 10.2 ha. Wetland size categories were $<2,2-4$, and $>4$ ha. Two to 1020 -m radius circular stations were used to count birds on each wetland, with the number of plots based on wetland size. The first count station was located along a randomly selected compass bearing. Subsequent stations were systematically located at equal distances from each other around the wetland. Stations were placed in the middle of the emergent vegetation zones or at the water's edge if emergent vegetation was not present. Surveys lasted for 6 minutes. Taped calls were used to elicit responses from secretive bird species (Virginia Rail, Sora, Least Bittern, and American Bittern) 
during minutes three and four of the count. Birds detected between count stations also were recorded. Evidence of breeding included active nests, young, or the presence of adults on three of five visits.

Percent vegetation cover was estimated along two to six linear transects with 1-m2 quadrats placed at 4-m intervals. Transects were randomly placed in the wetland, with the number varying with wetland size. Transects began at the wetland's high-water mark and continued through the center of the wetland to the opposite shore. Vegetative cover categories were emergent vegetation, residual (last year's growth) emergent vegetation, floating vegetation (e.g., duckweed [Lemna spp.], marsh smartweed [Polygonum amphibium], and floating mats of algae), submergent vegetation, open water, and bare ground. Water depth and vegetation height were measured in the center of each $1-\mathrm{m}^{2}$ plot. Vegetation was sampled in late June or early July.

The most common species nesting on restored wetlands in both years were Red-winged Blackbird, Yellow-headed Blackbird, and Marsh Wren. Other species that nested in both years were American Coot, Canada Goose, and Pied-billed Grebe. Species richness was significantly and positively related to wetland area in both years. Although mean species richness did not differ between wetland age categories 1 and 2 in 1989, the species-area slope was steeper for wetlands 2 yr old than for 1-yr-old wetlands. The mean species richness and species-area slope did not differ between age 2 and 3 wetlands in 1990. No significant relationship existed between mean water depth and species richness in either year. Species richness did not differ between wetlands drained $>30$ yr ago than wetlands drained $\leq 30$ yr ago. Species richness was significantly and positively related to the area of floating plants in both years and to the area of emergents in 1989. In 1989, species richness was significantly greater in wetlands with $>30 \%$ emergent cover than in wetlands with $\leq 30 \%$ emergent cover. In 1989, species richness was significantly greater in wetlands with $>1 \%$ floating plant cover than in wetlands with $\leq 1 \%$ cover. Species richness was not related to residual emergent or submergent vegetative cover. In 1989, species richness was greatest in marshes with moderate (30-70\%) coverages of open water. In both years, species richness was lower in wetlands with $>5 \%$ bare ground. Virginia Rail occurred in two of 33 restored wetlands and nested only on the largest restored wetland studied (9.3 ha) in 1990.

Horak, G. J. 1964. A comparative study of Virginia and Sora rails with emphasis on foods. M.S. thesis. Iowa State University, Ames, Iowa. 73 pages.

Food habits, plumage, and nest-site selection of Virginia Rails and Soras were studied in Iowa during 1962-1964. Rails were captured and killed for food analyses using two types of drive-traps made of 1.27-cm mesh hardware cloth and measuring either $90 \mathrm{~cm}$ long, $60 \mathrm{~cm}$ wide and $60 \mathrm{~cm}$ tall (box trap) or $90 \mathrm{~cm}$ wide and $3 \mathrm{~m}$ tall and formed into a cloverleaf shape. Leads were made of 2.54-cm mesh chicken wire and were $22.5 \mathrm{~m}$ long, $60 \mathrm{~cm}$ wide, and attached to the sides of the funnel entries of both types of traps. Leads were angled toward the traps at a $60^{\circ}$ angle. Traps were set perpendicular to the shore and in the wetland vegetation, with one lead extending onto dry land, and the other extending into the vegetation and out into the open water of the wetland. Traps were checked twice per day. A second method of killing rails for food analyses was the use of a .22 caliber pistol and shot-shells. Nests were located in 1962 by a previous researcher and in 1963 as part of the current study. No methods for nest-searching 
were given. At each nest, the following variables were recorded: species, cover type, height of cover, nest material, water depth, and date. Twenty-one Virginia Rail nests were found.

Johnson, R. R. 1984. Breeding habitat use and postbreeding movements by Soras and Virginia Rails. M.S. thesis. Iowa State University, Ames, Iowa. 52 pages.

Results of call playback surveys, characteristics of breeding and brood-rearing habitat, and movements were studied for Virginia Rails and Soras in northwestern Iowa in 1981 and 1982. Playback routes were established along wetland margins in Dewey’s Pasture Game Management Area and Spring Run Game Management Area, Iowa. Routes consisted of a total of 108 stations that averaged $100 \mathrm{~m}$ apart. A total of 65 ha of wetland was surveyed.

Recordings consisted of 1 minute continuous loop tapes of the primary advertising calls of the Virginia Rail and Sora, broadcasting at seven calls per minute. Recordings were broadcast on a Sharp model RD-664AV cassette recorder with a maximum sound pressure of $90 \mathrm{db} 1 \mathrm{~m}$ from the source. Counts occurred from 1 May to 16 June 1981 and from 15 April to 1 June 1982. Counts were conducted from $1 \mathrm{~h}$ before sunrise to $3 \mathrm{~h}$ after sunrise and were not done in winds $>24 \mathrm{kph}$ or in heavy rain. Night counts occurred from 1-4 h after sunset in early June. At each station, Virginia Rail and Sora calls were played for 2 minutes, alternating which species was played first. For each rail response, the call that was played first, the call (Virginia Rail or Sora) responded to, the estimated location, and distance of each responding rail were recorded. Territory locations were defined by simultaneous pair responses on individual surveys or clusters of responses from repeated surveys. Habitat structure of 92 Virginia Rail and 71 Sora territories was examined using 20-25-m transects that were centrally located on territories and positioned to cross wetland vegetation. The following variables were recorded in 1-m2 quadrants placed at 2$\mathrm{m}$ intervals along the transect: stem count by species, water depth, visual obstruction (Robel pole reading), total stem density, and the amount of floating residual vegetation, measured in categories from 0 to 4 (low to high amounts of residual vegetation). In 1982, vegetation variables were measured at 50 random locations. Vegetation cover types were cattail (Typha spp.), bur-reed (Sparganium eurycarpum), sedges (Carex spp.), river bulrush (Schoenoplectus fluviatilis), hardstem bulrush (Schoenoplectus acutus), and miscellaneous (species included in miscellaneous category not specified).

Five hundred twenty-eight Virginia Rail responses to taped calls were recorded during 1981-1982 from 108 survey stations.

Johnson, R. R., and J. J. Dinsmore. 1986. The use of tape-recorded calls to count Virginia Rails and Soras. Wilson Bulletin 98:303-306.

The effectiveness of tape-recorded call surveys for Virginia Rails and Soras was studied on two wetland complexes in northwestern Iowa, 1981 and 1982. A total of 108 count stations were established at a mean interval of $100 \mathrm{~m}$ around the perimeter of wetlands. A total of 65 ha of wetlands were surveyed, including 52 ha of emergent vegetation. One-minute continuousloop tapes of the primary advertising call of the Virginia Rail and Sora were broadcast continuously for 2 minutes at each station. The call broadcast first was alternated at each station. The location of calling rails was noted on aerial photographs of the wetlands. Counts were 
conducted between 1 May and 16 June in 1981 and between 15 April and 1 June in 1982. Counts were conducted at least once per week and were made from $1 \mathrm{~h}$ before to $3 \mathrm{~h}$ after sunrise and they were not performed when wind velocity exceeded $24 \mathrm{kph}$ or in heavy rain. Night surveys also were conducted in early June of each year from 1 to $4 \mathrm{~h}$ after sunset.

A total of 528 Virginia Rail and 470 Sora responses were recorded. Soras that responded to morning broadcasts were significantly farther away (average of $68 \mathrm{~m}, \mathrm{n}=470$ ) than Virginia Rails (average of $51 \mathrm{~m}, \mathrm{n}=504$ ). Chi-square analysis of the data indicated that Soras responded to conspecific calls significantly more often than to Virginia Rail calls. Virginia Rails exhibited a higher responsiveness to conspecific calls during the postlaying period.

The authors suggest that in areas where Virginia Rails and Soras are sympatric, both species may be counted during the prelaying period by broadcasting the primary advertising call of the Sora. During the postlaying period, best results would be achieved by broadcasting calls of both species. The authors state that night counting seemed to be useful in obtaining indices to breeding rail densities. Night counts generated higher Virginia Rail counts and they responded over a greater radius than during morning surveys. It was noted that the peak of egg-laying for both species was mid-May.

Manci, K. M., and D. H. Rusch. 1989. Waterbird use of wetland habitats identified by infrared aerial photography. Pages 1045-1058 in R. R. Sharitz and J. W. Gibbons, editors. Freshwater wetlands and wildlife. Proceedings of a symposium held at Charleston, South Carolina, March 24-27, 1986. U.S. Department of Energy, Office of Scientific and Technical Information, Oak Ridge, Tennessee.

Wetland bird use of emergent and open-water habitats in Horicon Marsh, Wisconsin, were examined during the summers of 1981 and 1982. One of the objectives of the study was to determine whether infrared aerial photographs could be used to identify wetland habitats. Another objective was to identify habitats used by wetland birds from early April to mid-August. Infrared aerial photographs were taken in June. Wetland birds were censused weekly on 25 1ha plots located along roads and on 25 1-ha plots along airboat routes. Details on spacing of plots or the technique for marking plots were not given. Routes along roads were censused weekly from the first week in April to mid-August in 1981 and 1982; airboat routes were censused weekly from the third week in May through mid-August in both years. Censuses along roads occurred between 0700 and $1100 \mathrm{~h}$, whereas censuses along airboat routes occurred between 1100 and $1400 \mathrm{~h}$. A cassette recorder was used to note the habitat in which each bird was found, the number, and, if possible, sex and age of each bird. Taped calls were used to elicit responses from rails, bitterns, and wrens. One playback count 7 minutes in length (additional details on playback counts were not given) was conducted within each plot. Any other birds calling or flushed during the 7-minute stop also were recorded. Bird activity (feeding, resting, locomotor, preening, alert, or social displays) was noted to determine if certain behaviors occurred in specific habitats. Bird activities were observed weekly from the 251 -ha plots on road routes (bird activity was often disrupted by the airboats). Routes were randomized each week such that birds were observed during all hours of daylight. Birds were observed through binoculars or a spotting scope from the truck window or platform in the truck bed. Following a 2-minute pause at each plot, observers recorded species, sex and age (if possible), habitat, and activity for individual birds using the "scan” sampling method (Altmann, J. 1974. 
Observational study behavior: sampling methods. Behaviour 49:227-265.). The "scan" method notes bird activity when first observed. Open-water habitat categories were water-filled, manmade ditch (mean water depth of $82 \mathrm{~cm}$ ), clear deepwater (mean water depth of $50 \mathrm{~cm}$ ), turbid deepwater (mean water depth of $52 \mathrm{~cm}$ ), and shallow water (mean water depth of $20 \mathrm{~cm}$ ). Five major emergent plant habitats were identified: deep-water cattail (Typhus spp.; mean water depth of $29 \mathrm{~cm}$ ), dry cattail (mean water depth of $3 \mathrm{~cm}$ ), shallow-water cattail (mean water depth of 7$10 \mathrm{~cm}$ ), river bulrush (Schoenoplectus fluviatilis; mean water depth of 7-10 cm), and sedge (Carex spp.; $<7 \mathrm{~cm}$ water depth). In general, water-filled ditches were used by birds more than expected based on availability. Shallow water was the next most selected habitat.

Naugle, D. E., K. F. Higgins, and S. M. Nusser. 1999. Effects of woody vegetation on prairie wetland birds. Canadian Field-Naturalist 113:487-492.

Avian use of wetlands surrounded by woody vegetation was studied throughout South Dakota during the summers of 1995 and 1996. A grid of $25.9 \mathrm{~km}^{2}$ cells was overlaid onto a geographic information system (GIS) constructed of National Wetland Inventory (NWI) data for eastern South Dakota. Wetlands in western South Dakota were randomly selected using 7.5-minute NWI maps, because wetlands west of the Missouri River had not yet been digitized. An average of two seasonal and two semipermanent wetlands were surveyed for birds within 216 randomly selected cells. An adequate sample of all wetland sizes were surveyed. Wetland area was estimated using either the NWI maps and a planimeter or using the GIS. During surveys, the proportion of emergent vegetation within wetlands was estimated visually (Daubenmire, $\mathrm{R}$. F. 1959. A canopy-coverage method of vegetational analysis. Northwest Science 33:43-64.), and these values were used as covariates. Categories for the percentage of vegetated area within wetlands were $0,1,2-5,6-25,26-50,51-75,76-95$, and $>95$.

Birds were surveyed for 8 minutes within 18-m fixed-radius circular plots. Tape recordings of Virginia Rail, Sora, Least Bittern, and American Bittern were broadcast to elicit responses from these secretive species. A 3-minute continuous loop tape was played. It consisted of 25 seconds of male territorial calls of each of the four species followed by 5 seconds of silence and was played for 2 minutes at each circular plot. The third minute of calling repeated 10 seconds of calls for each species, interspersed with 5 seconds of silence. Calls were broadcast during the 3-5 minute period of each 8-minute survey. The number of circular plots surveyed per wetland increased with increasing wetland area and were dispersed evenly throughout the wetland. Coverage ranged from $100 \%$ of small (not defined) wetlands to $<1 \%$ of large wetlands. When no vegetation was present in the wetland, birds were surveyed before approaching the wetland. Species detected outside of plots or while moving between plots were recorded and the entire wetland perimeter was traversed to ensure that each species present in the wetland was recorded. Surveys were done from sunrise to $1000 \mathrm{~h}$ or $1800 \mathrm{~h}$ to sunset and were not conducted during rain or high $(\geq 24 \mathrm{kph})$ winds. Species using woody vegetation along wetland margins also were noted. The proportion of the wetland edge occupied by woody vegetation was categorized as $<1 \%, 1-5 \%, 6-25 \%, 26-50 \%, 51-75 \%, 76-95 \%$, and $>95 \%$.

Wetland bird species richness decreased as the proportion of woody vegetation along the wetland perimeter increased. An initial decline of wetland bird species richness occurred at the point when $>25 \%$ of the wetland perimeter was occupied by woody vegetation. The most significant declines of wetland bird species richness occurred when the wetland perimeter was 
$>75 \%$ covered with woody vegetation. The negative impact of woody vegetation on wetland bird species use was not completely understood, but authors suggested negative impacts may include perches for predatory raptors and parasitic Brown-headed Cowbirds.

Naugle, D. E., R. R. Johnson, and K. F. Higgins. 2001. A landscape approach to conserving wetland bird habitat in the Prairie Pothole Region of eastern South Dakota. Wetlands 21:1-17.

Local and landscape-level factors affecting the presence or absence of 20 wetland bird species were examined in eastern South Dakota during 1995 and 1996. Investigators surveyed 416 semipermanent and 418 seasonal wetlands (wetland classification by Cowardin, L. M., T. L. Shaffer, and P. M. Arnold. 1995. Evaluation of duck habitat and estimation of duck population sizes with a remote-sensing-based system. U.S. Fish and Wildlife Service, National Biological Survey, Washington, D.C., USA. Biological Science Report No. 2) from 5 May to 10 July in both years. Surveys were conducted from sunrise to $1000 \mathrm{~h}$ and from $1800 \mathrm{~h}$ to sunset and were not done in rain or winds $>24 \mathrm{kph}$. The open water areas of a wetland were observed from a vantage point prior to entering the wetland. All birds seen or heard were recorded. Tape-recorded calls of Virginia Rail, Sora, Least Bittern, and American Bittern were played at a set number of predetermined points. The number of points per wetland varied with wetland area: one point for wetlands $<0.5$ ha, two points for wetlands $0.5-5$ ha, three points for wetlands $5-10$ ha, and four points for wetlands $>10$ ha. At each point the observer listened passively for 3 minutes, then began a 3-minute tape of recorded calls (length of calls not given). Observers walked through the emergent vegetation zone and then around the perimeter of the wetland to ensure that all species present were detected. Vegetative wetland stage (e. g., degenerating vs. open marsh) was recorded. Percent cover of vegetation (<1\%, 1-5\%, 6-25\%, 26-50\%, 51-75\%, $76-95 \%$, and $>95 \%$ ) and grazing intensity (idle to heavily grazed) were recorded for each wetland. Percent of the wetland edge occupied by woody species and whether the land adjacent to the wetland was tilled or untilled were recorded. Wetland vegetation heterogeneity was described by recording the number of dominant emergent vegetation types composing $>10 \%$ of the vegetation cover. Wetlands were categorized as being dominated by thick-stemmed emergent vegetation (cattail [Typha spp.]) or by thin-stemmed emergent vegetation (spikerush [Eleocharis spp.] and sedges [Cyperaceae]). Other variables used to evaluate habitat suitability were wetland area, wetland type, and shoreline length. Landscape-scale factors quantified within $25.9 \mathrm{~km} 2$ cells surrounding surveyed wetlands were grassland area, and total area and density of wetlands for four wetland classification categories (temporary, seasonal, semipermanent, and permanent; Stewart, R. E., and H. A. Kantrud. 1971. Classification of natural ponds and lakes in the glaciated prairie region. Resource Publication 92. U.S. Fish and Wildlife Service, Bureau of Sport Fisheries and Wildlife. 57 pages.). National Wetlands Inventory database and Landsat Thematic Mapper Imagery were used to identify wetlands and upland habitat types (tilled and untilled vegetation), respectively. Untilled lands were permanent pastures, Conservation Reserve Program lands, and alfalfa (Medicago sativa).

Presence of Virginia Rails in semipermanent wetlands was positively associated with wetland area, percent of the wetland area that was vegetated, and with wetlands dominated by thick-stemmed plants. Presence in seasonal wetlands was positively associated with percent of the wetland area that was vegetated and with wetlands dominated by thick-stemmed plants. 
Pospichal, L. B. 1952. A field study of Sora Rail (Porzana carolina) and Virginia Rail (Rallus limicola) populations in central Minnesota. M.S. thesis. University of Minnesota, St. Paul, Minnesota. 80 pages.

Trapping, marking, sexing, and aging techniques for Virginia Rails and Soras, as well as general ecology of Virginia Rails and Soras, were studied near St. Paul, Minnesota during 1949-1951. Nesting ecology will be the focus of this summary. Seven semipermanent wetlands were studied, all located within tracts of agricultural land and four of which had been previously drained, but had refilled due to malfunctioning of drainage devices. Wetlands were 0.3 to 1.4 ha in size, had water depths ranging from $15 \mathrm{~cm}$ to $1.2 \mathrm{~m}$, and were dominated by cattail (Typha spp.), softstem bulrush (Schoenoplectus tabernaemontani), river bulrush (Schoenoplectus fluviatilis), northern water plantain (Alisma triviale), and arrowhead (Sagittaria latifolia). Wet-meadow zones were dominated by bluejoint (Calamagrostis canadensis), reed canary grass (Phalaris arundinacea), American sloughgrass (Beckmannia syzigachne), sedges (Carex spp.), path rush (Juncus tenuis), needle spikerush (Eleocharis acicularis), and duck millet (Echinochloa pungens). Floating aquatic plants were duckweed (Lemna spp.), liverwort (Riccia fluitans), and algae. Submerged aquatic plant species were pondweed (Potamogeton spp.), and muskgrass (Chara spp.).

Rails were captured using single- funnel traps $(60 \mathrm{~cm}$ by $60 \mathrm{~cm}$ by $60 \mathrm{~cm}$ and built of 2.54-cm mesh netting) or double-funnel traps ( $30 \mathrm{~cm}$ by $60 \mathrm{~cm}$ by $45 \mathrm{~cm}$ and built of $1.27-\mathrm{cm}$ hardware cloth). In addition, single-funnel traps measuring $60 \mathrm{~cm}$ by $60 \mathrm{~cm}$ by $90 \mathrm{~cm}$ and made of 1.9-cm mesh hardware cloth were used for drive-trapping. Traps were equipped with woven 1.27-1.9-cm drift fences that were $90 \mathrm{~cm}$ by $10.5 \mathrm{~m}$. Drift fences were set up at acute angles so that rails wouldn't run into them head-on and become overly excited, and extended beyond the vegetation to prevent rails from escaping around the fence edges (rails rarely take to the open water). Drift fences were constructed of either cloth netting, wire netting, or plastic-coated screen. A net canopy was arranged over the junction of the drift fence and the trap to prevent birds from flushing at the mouth of the funnel. Birds were trapped by driving them slowly toward traps or allowing birds to enter traps passively in overnight sets. From one to three persons conducted drive-trapping, walking slowly side by side in a zig-zag pattern through the vegetation. Seventy-eight adult rails were captured using drive-trapping and 25 rails were trapped in overnight sets, of which 21 were juvenile rails. Drive-trapping was found to be most practical during early spring and summer, sometimes in late fall. Several marking techniques were attempted in the early spring, but all rails marked except one were apparently migrants, because they were never seen again after marking. Marking techniques included U.S. Fish and Wildlife Service \#3 leg bands, colored celluloid leg bands, painting flight feathers, painting undertail coverts, and clipping fish-fingerling tags into the patagium of the right wing. The latter technique required that the rail be in hand to see the tag.

Nests were located by systematically searching emergent cover on foot. Wetlands were traversed in intervals of 1.2-1.8 m. Twelve Virginia Rail nests were discovered and measured.

Prescott, D. R. C., M. R. Norton, and I. M. G. Michaud. 2001. A survey of Yellow and Virginia rails in Alberta using nocturnal call playbacks. Unpublished report by the Alberta Conservation Association, Edmonton, Alberta. 20 pages. AND 
Prescott, D. R. C., M. R. Norton, and I. M. G. Michaud. 2002. Night surveys of Yellow Rails, Coturnicops noveboracensis, and Virginia Rails, Rallus limicola, in Alberta using Call Playbacks. Canadian Field-Naturalist 116:408-415.

Current distributions of Yellow Rails and Virginia Rails were determined by conducting nocturnal field surveys using call playbacks at 404 sites in Alberta from 17 May to 6 July 2000. This included 17 sites that were visited twice and five sites that were visited three times. Current distribution was compared to historical records. Objectives of the study were to identify sites where the species historically occurred, conduct surveys of those sites to determine whether the species was still present, identify suitable habitat and new potential breeding sites, and gain a better understanding of the habitat requirements and calling behavior of the species to improve the effectiveness of field surveys.

Historical locations for Yellow Rail and Virginia Rail were obtained from the Biodiversity/Species Observation Database, the Alberta Bird Checklist Program, Alberta Bird Atlas database, known published reports, museum collections, the Breeding Bird Survey database, provincial publications, and internet news group publications.

Nocturnal surveys were conducted between 20 May and 25 July and began at sites in the southern portion of the province to reflect earlier arrival of birds there. Past studies indicated that the probability of detection for these species during a single visit was $75 \%$. When logistically possible, second visits were occasionally made to some sites. In the cases of older sites that were not well described, 2-5 areas of suitable habitat within $5 \mathrm{~km}$ of the expected location were surveyed. Alberta Bird Atlas database records were compiled by $100-\mathrm{km}^{2}$ blocks; 2-5 areas of suitable habitat were surveyed within these blocks. All surveyed sites were visited during the daytime to identify access points, identify new areas of potential habitat, record dominant vegetation (percentage of cover types [standing emergents, open water, bare ground, shrubs, or trees]), record wetland permanency (permanent, semipermanent, or seasonal), and georeference the site using a global positioning system. Dominant vegetation categories were cattail (Typha spp.), bulrush (Schoenoplectus spp.), sedge (Carex spp.), or mixed (cattail/bulrush/sedge).

Surveys were conducted between sunset and sunrise, using calls of conspecifics to increase the probability of detection. Call playbacks were obtained from commercial sources and played from a height of about $1.5 \mathrm{~m}$ and a volume between 80 and $95 \mathrm{db}$. Although surveys were conducted under a range of conditions, periods of $>20 \mathrm{kph}$ winds or heavy rainfall were avoided. Steps in conducting surveys were as follows: 1) 3-minute listening period, 2) three, 20-second playbacks of Yellow Rail calls ("clicks") separated by 20 seconds of silence, and three 20-second playbacks of Virginia Rail calls (two sets of descending "grunts" and one set of combined "kadic-kadic" and "kicker" calls [vocalizations most often used in territorial calling and mate attraction]), and 3) a final 3-minute listening period. Data recorded included number of birds calling during each of the pre-playback, playback, and post-playback periods, air temperature, wind speed, precipitation or fog, percent cloud cover, moon phase (new, <half full, $>$ half full, or full), moon visibility (visible, obscured, or absent), and time of night (early = 1000 to $1159 \mathrm{~h}$; middle = 2400 to $0159 \mathrm{~h}$, and late $=0200$ to $0530 \mathrm{~h}$ ).

Virginia Rails were found in a wide variety of semipermanent and permanent wetlands. They were detected more often when the moon was more than half full and relatively unobscured by clouds. Yellow Rails were found in seasonal wetlands containing sedges. They were most 
likely to be detected when there was little or no moon, and during the darkest part of the night. Playbacks were more effective at detecting Virginia Rails, as the number of spontaneously calling individuals was lower (55\%) than for Yellow Rails (80.4\%).

Prince, H. H. 1985. Avian communities in controlled and uncontrolled Great Lakes wetlands. Pages 99-120 in H. H. Prince and F. M. D’Itri, editors. Coastal Wetlands. Lewis Publishers, Inc., Chelsea, Michigan.

Breeding bird use of four Great Lakes coastal wetlands was compared between wetlands with and without artificial water control mechanisms from 1980 to 1983 . The study areas were located in Michigan. Two wetlands had natural water fluctuations and two wetlands were artificially controlled. Three of the four wetlands had established emergent vegetation. The fourth wetland had been restored from agricultural use three years prior to the study, so vegetation was in developmental stages.

A total of 24 belt transects (30 $\mathrm{m}$ in width and totaling 11,000 m) were established on a random basis in the four wetlands. Sample areas were equal among the four wetlands. Vegetation was measured, and nest, flush, and call counts were made along the transects. Above-ground primary productivity of emergent plants was measured by weighing dried stem samples from cattails and by counting stem densities in a series of $1-\mathrm{m} 2$ plots. Ratios of emergent vegetation cover to open water were estimated.

Three nest searches were conducted on each wetland in each year. An early-season search was conducted between late April and mid-May, a mid-season search was done between the last week in May and mid-June, and a late-season search was done between late June and mid-July. Each belt transect was divided into 5-m search zones; one person searched for nests in each zone (article did not specify whether person was on foot or in a boat). Nest variables recorded were species, status of eggs/young, height, nesting substrate, and location along the transect. Taped calls were used to detect Sora, Virginia Rail, American Coot, and Common Moorhen. Call counts were conducted at 100-m intervals along belt transects between sunrise and $1100 \mathrm{~h}$ at 2-week intervals from May through September. Counts were not made when winds exceeded $16 \mathrm{kph}$. Recorded calls were played at each station using speakers aimed in opposite directions. The direction and estimated distance (how this was determined was not specified) were recorded for 1 minute after the tape was stopped. Number of calls of individual species and length of call playbacks were not specified. Large wading birds and waterfowl were counted biweekly along each belt transect in conjunction with call playback counts.

A total of 907 nests were found over the 4-yr period. The number of species nesting and nest density were significantly, negatively related with the percent of open water per $100 \mathrm{~m}$ of transect.

Reid, F. A. 1989. Differential habitat use by waterbirds in a managed wetland complex. Ph.D. dissertation. University of Missouri, Columbia, Missouri. 240 pages.

Avian use of seasonally flooded wetlands on the Ted Shanks Wildlife Area in northeastern Missouri was examined from 1981 through 1985. Habitat partitioning of six waterbirds (Sora, King Rail, Yellow Rail, Virginia Rail, Least Bittern, and American Bittern) 
were studied during spring and fall migration. Breeding and foraging ecology of King Rails, and the response of wading birds to controlled drawdowns of a managed wetland, also were examined. Observations of birds were made at specific flush sites in the spring and fall of the year. Birds were flushed by walking the entire wetland area or using strip transects. Surveys were conducted from April to late May and mid-August to mid-October between 0700-1000 h and 1700-2000 h.

Ribic, C. A. 1999. Rails in Wisconsin, with a focus on Sora and Virginia Rail. Passenger Pigeon 61:277-289.

Distribution and habitat preferences for the Virginia Rail and Sora were studied in Wisconsin in 1997 and 1998. Distribution information was obtained from the U.S. Geological Survey Breeding Bird Survey (BBS) and the Wisconsin Breeding Bird Atlas. Surveys for rails were conducted in southern portions of Wisconsin. Surveys were conducted at 63 points during May-June 1997 and from 89 points during May-June 1998. Survey points were located along roads or dikes near wetland edges and were $\geq 250 \mathrm{~m}$ apart. Each point was surveyed twice each year. Tape-recorded calls were played to elicit responses from Sora, Virginia Rail, King Rail, Black Rail, Yellow Rail, American Bittern, and Least Bittern. Surveys occurred from 0430 to $1000 \mathrm{~h}$. Surveys were not conducted when winds were $>24 \mathrm{kph}$, when temperatures were $>85 \mathrm{oF}$, or in rain or fog. Rails heard or seen within an 80-m (1997) or 100-m (1998) radius half circle in front of the observer were recorded. At each survey point, the researchers paused for 2 minutes, passively listened for calling rails for 5 minutes, and then played 8 minutes of tape-recorded calls that consisted of species' calls repeated three times with 10 seconds of silence in between calls. The tape was followed by a 1-2-minute listening period.

Percent coverages of vegetation species were visually estimated at each survey point in June each year. If a species made up $\geq 50 \%$ cover for a point, it was categorized as being dominated by that plant species. For more information on methodology, see Graetz, J. L., S. W. Matteson, J. Skoloda, and C. Ribic. 1997. Status and distribution of marsh and sedge meadow birds at Horican, Necedah, and Trempealeau national wildlife refuges. Passenger Pigeon 59:119-130. In 1997, 21 points were dominated by cattail (Typha spp.) and 42 by sedge (Carex spp.). In 1998, 35 points were dominated cattail and 54 by sedge. Virginia Rails were more likely to call during the playback tapes than during the passive listening period. Virginia Rails were more often heard in May than in June. Soras were more likely to call during the playback tapes than during the passive listening period. Soras were more often heard in May than in June. Soras were detected at $47 \%$ of 56 survey points dominated by cattail and at $29.9 \%$ of 96 survey points dominated by sedge.

Rundle, W. D., and L. H. Fredrickson. 1981. Managing seasonally flooded impoundments for migrant rails and shorebirds. Wildlife Society Bulletin 9:80-87.

Effects of seasonal flooding of four managed shallow-water impoundments (moist-soil units) on use by migrating rails and shorebirds was studied in the Mississippi River lowlands of Stoddard and Wayne counties in southeastern Missouri from 1978 to 1980. One impoundment was managed for rails, two impoundments were managed for shorebirds, and the control 
impoundment was managed for waterfowl. Moist-soil units generally were flooded in November and December and drained beginning in May. Rails were censused from mid-March through May, and from mid-July through November. Rails were flushed from wetland vegetation with the aid of a trained dog, and total numbers of individuals were recorded by species.

Rail use sites (flush locations) were marked and vegetation within $0.5 \mathrm{~m}$ was described. Water depth, distance to the nearest soil/water interface, and all plant species were recorded. Rails used moist-soil units with robust perennial vegetation in advanced successional stages. Units used by rails were partially vegetated with sedges (Carex spp.), bulrushes (Schoenoplectus spp.), and woody shrubs, especially trumpet-creeper (Campsis radicans) and false indigo (Amorpha fruticosa). Rails probably selected habitat based on water depth and vegetation structure rather than plant species composition. Water depths at sites used by Virginia rails ranged from 0 to $27 \mathrm{~cm}$ and averaged $7.3 \mathrm{~cm}$ at eight flush locations. Most (6 of 8) Virginia Rails were flushed from water $<15 \mathrm{~cm}$ deep. Virginia Rails were most common in a moist-soil unit characterized by water depths of 5-15 cm and mixed stands of beggarticks (Bidens spp.), late-flowering thoroughwort (Eupatorium serotinum), and barnyard grass (Echinochloa muricata and E. crusgalli).

Sayre, M. W., and W. D. Rundle. 1984. Comparison of habitat use by migrant Soras and Virginia Rails. Journal of Wildlife Management 48:599-605.

Habitat use of migrating Soras and Virginia Rails was studied on moist-soil management units (seasonally flooded impoundments) within Mingo National Wildlife Refuge in southeastern Missouri from 1979 to 1981. The impoundments ranged in size from 8 to 20 ha. Surveys for Soras and Virginia Rails were conducted during September and October and again the following April and May along transects spaced $40 \mathrm{~m}$ apart (total transect length not specified). A trained dog was used to locate rails. During randomly selected surveys, the flush locations of rails were marked and vegetation was measured at these sites. Eventual flush locations of rails that initially ran from the dog were excluded. Flush locations of rails detected along survey routes were marked and habitat variables were measured at these locations. Water depth, vertical and horizontal density of vegetation at $5,10,20,30,50,70$, and $100 \mathrm{~cm}$ above the substrate (using a point intercept method), distance to nearest soil-water interface (if $<5 \mathrm{~m}$ away), and identification of all plant species within a $0.5 \mathrm{~m}$ radius of the flush site were measured at each flush site. Habitat use was compared to availability for one management unit, and availability was estimated from 20 random locations along three randomly located transects. Water depths ranged from 0 to $29.7 \mathrm{~cm}$ at all 27 Virginia Rail flush sites, and $70 \%$ of flush sites had $<5 \mathrm{~cm}$ of water.

Schreiber, J. A. 1994. Structure of breeding-bird communities on natural and restored Iowa wetlands. M.S. thesis. Iowa State University, Ames, Iowa. 85 pages.

Breeding-bird communities and nest site selection by birds were compared between seven natural and 14 restored wetlands in northwestern Iowa in 1992 and 1993 . Wetlands selected for study were in the "hemi-marsh" stage (40-60\% emergent vegetation) in 1992. The guild structure of breeding birds in natural and restored wetlands also was compared. Seven 
wetlands were studied in each of three categories: unaltered natural wetland, restored/first flooded in 1988 (R-88), and restored/first flooded in 1991 (R-91). All of the wetlands selected for study were in the hemi-marsh stage in 1992, were 0.8-3.0 ha in size, and were part of wetland complexes. All restored wetlands had been completely drained prior to restoration with drainage tile and had been row cropped. Birds were surveyed at three random points in the emergent vegetation or at the water's edge at each wetland. All birds seen or heard were recorded within an 18-m radius of each survey point and taped calls of Sora, Virginia Rail, Least Bittern, and American Bittern were played to elicit responses from these birds. Frequency of occurrence of Virginia Rails was significantly greater for natural wetlands than for R-91 wetlands in 1992 and for both R-88 and R-91 wetlands in 1993.

Schuster, J. E. 1998. Avian community composition and diversity in natural and restored central Iowa wetlands. M.S. thesis. Iowa State University, Ames, Iowa. 74 pages.

Species richness, frequency of occurrence, and guild structure of breeding bird communities were compared in six natural and six restored wetlands in central Iowa in 1996 and 1997. Wetlands had been tile-drained and row-cropped prior to restoration. Wetlands were 0.4-4.0 ha in size and were located in Boone, Dallas, Greene, Hamilton, Polk, and Story counties in central Iowa. Age of restored wetlands varied from 1 to $7 \mathrm{yr}$ post-flood, and most were 3- to 5 -yr old in 1996. All of the wetlands but one were in a hemi-marsh (40-60\% emergent vegetation cover) stage during both years. Birds were surveyed in each wetland using two survey points ( $25 \mathrm{~m}$ radius circles) located in the middle of the emergent vegetation. Surveys were conducted once a week from mid-May to early July. Taped calls were played to elicit responses from Soras, Virginia Rails, American Bitterns, and Least Bitterns. In both years, the mean number of species per wetland and the mean number of breeding species per wetland were not significantly different in natural and restored wetlands. In 1996, there was a slight significant difference between natural and restored wetlands for the number of breeding birds per 25-m radius circle, with higher densities found in restored wetlands. There was no significant difference in 1997. No significant relationship was found between the mean number of total birds or mean number of breeding birds and wetland area. Frequency of occurrence of Virginia Rails was greater in natural wetlands than in restored wetlands in the first year, but was equal between natural and restored wetlands in the second year of the study.

Shutler, D., A. Mullie, and R. G. Clark. 2000. Bird communities of prairie uplands and wetlands in relation to farming practices in Saskatchewan. Conservation Biology 14:1441-1451.

Effects of conventional farming, organic farming, and minimum-tillage farming practices on composition of avian communities were compared to untilled areas in southcentral Saskatchewan in 1996 and 1997. Fields used in the study were within a 200-km radius of Saskatoon. Conventional farming involved the use of agrochemicals and tillage ( $>3$ times per year) to control weeds. Organic farming involved tilling more frequently than for conventional farming (exact number of times fields were tilled was not specified), but without the use of agrochemicals; chemicals had not been used for at least 4 years. Minimum-tillage farming involved reduced tillage ( $<3$ times per year) and direct seeding into the previous year's crop 
stubble. Untilled areas were lands taken out of crop production; some were seeded to nesting cover or planted for hay production, and they were not tilled and had no or low chemical applications. Vegetation was native and tame.

Fixed-radius (100-m radius) point counts were conducted within cereal fields, usually wheat, in untilled fields, and in wetlands. In cereal fields, a buffer zone of $100 \mathrm{~m}$ was allowed around point counts where possible. In small wetlands, the entire wetland was censused, including noncrop margins. In large wetlands, plots were semicircular with a fixed radius of 100 $\mathrm{m}$ and included noncrop margins within the radius. Birds flying over plots were not counted in the survey unless they were swallows flying $<2 \mathrm{~m}$ above the wetland. Surveys were conducted between 12 June and 19 July 1996 and between 2 June and 4 July 1997, between 0430 and 0930 h. Surveys were not conducted during heavy wind (speed not specified) or rain. Most plots were surveyed twice during each year of the study, and the order of plot visits was reversed between the two surveys to reduce bias from time of day. In uplands, all birds seen or heard within the plot in a 5-minute interval were recorded. Playback calls were used for Pied-billed Grebe, American Bittern, Virginia Rail, and Sora; an extra 5 minutes were spent listening for responses to playback calls (detailed methods of playback calls were not given). Characteristics of point counts were noted, such as whether a buffer zone included wetlands, trees, or hedgerows. The number of wetlands, the area of wetland basin plus noncrop margins, and area of woody vegetation were summarized for the quarter section (64 ha) in which a plot was located. These characteristics were measured both on the ground and from digitized aerial photos. Wetland plots had to be at least $0.5 \mathrm{~m}$ deep in June 1996 and occupy a basin $<10$ ha. Area of basin included open water, wet meadow, and emergent vegetation. Area of water was defined as the area of open water estimated in July. Percent woody margin was the area occupied by trees and shrubs. Complexity was a subjective score that rated wetlands according to the variety of habitats.

Untilled areas contained the most individuals and had the highest diversity than did farms. Among uplands, minimum-tillage fields had more individuals and species than did organic or conventional fields. Organic fields had slightly more individuals and species of birds than did conventional fields. Among wetlands, organic fields had higher relative abundance than minimum-tillage or conventional fields. Upland birds were more numerous and diverse in areas with nearby wetlands. Wetland birds were more numerous and diverse in areas with high diversity in habitat types.

Tacha, R. W. 1975. A survey of rail populations in Kansas, with emphasis on Cheyenne Bottoms. M.S. thesis. Kansas State College, Fort Hays, Kansas. 54 pages.

Breeding habitat requirements, breeding biology, local and migratory movements, and survey and trapping techniques of Virginia Rail, Sora, and King Rail were studied in Kansas during 1974-1975. The Cheyenne Bottoms wetland complex in Barton County was studied in 1974. Ten wetlands that were located in various parts of the state were surveyed in 1975 . Sizes of wetlands surveyed in 1975 ranged from 20 ha to 500 ha and areas studied within these wetlands ranged from 1 ha to 7.2 ha.

Recorded advertising calls were used to elicit responses from rails and to estimate breeding populations. In 1974, calls were played for 3 minutes at 100-m intervals along transects during the early morning (hours not specified). Transects were established in wetland 
vegetation and transect length varied according to wetland size. Species, dominant vegetation, water level, and whether responses were in singles or pairs were recorded. In 1975, 10 calls each of the King Rail and Virginia Rail were played alternately for 7 minutes. Three minutes of Sora calls were then played. Recordings were played at seven points (except Meade transect had only six points) at 80 -m intervals after a 5-minute waiting period. Surveys were conducted 30 minutes before sunrise or1 hour before sunset. Estimated distance and direction of the response were recorded. Each transect was surveyed 3 times during a 2-d census period and each transect was surveyed 12 times during the period from 27 March to 10 June. Population estimates were calculated based on playback surveys and trapping. Nests were located using various methods: 1) two or more persons dragging a rope (with noise-makers attached) through nesting cover, 2) using responses to taped calls to search for nests in occupied areas, 3) walking nesting cover in a compact grid pattern, and 4) using a Brittany Spaniel to flush adults from nests or locate nests by scent. Rails were captured using walk-in traps and 45-m drift fences. (Traps used were further described by Baird, K. E. 1974. A field study of the King, Sora and Virginia rails at Cheyenne Bottoms in west-central Kansas. M.S. thesis. Kansas State University, Manhattan, Kansas. 38 pages.) Traps were checked twice daily and rails were banded with U.S. Fish and Wildlife Service bands. Rails were measured, weighed, and aged. Trapping occurred from 6 June through 10 October, 1974 and 23 June and 11 August, 1975. One drift fence of the trap was set through the vegetation and parallel to the shoreline and the other ran out perpendicular to the shoreline and toward the center of the wetland.

Vegetation was sampled every $20 \mathrm{~m}$ along 100-m line transects established in a grid pattern throughout the wetland. Vegetation was sampled in August of 1974 and during late May and early June of 1975. Using a 180 degree exclusion angle (no other description given), the closest species of plant lying on one side of the transect line was recorded at each point. Percent species composition was calculated from this. The dominant species at each point was recorded.

Results revealed that at Cheyenne Bottoms all three species occurred in the same general habitat type, one dominated by alkali bulrush (Scirpus maritimus), cattail (Typha spp.), softstem bulrush (Schoenoplectus tabernaemontani), prairie cordgrass (Spartina pectinata), and saltgrass (Distichlis spicata) with water levels ranging from 0 to $15 \mathrm{~cm}$. Rail response differed significantly according to water depth. Of 581 responses from all species combined, 92.5\% occurred in water levels $<5 \mathrm{~cm}, 5.7 \%$ occurred in water levels up to $8 \mathrm{~cm}, 1.2 \%$ in water levels up to $10 \mathrm{~cm}$, and less than $1 \%$ occurred in water levels up to $25 \mathrm{~cm}$ or when water was completely absent. Seventy percent of 581 responses occurred when winds were $\leq 8 \mathrm{kph}$, and $81 \%$ occurred when winds were $<24 \mathrm{kph}$. Rails responded to recorded calls equally well in the morning and evening. Of 581 responses, 58.3\% occurred on clear days and $41.7 \%$ occurred on cloudy days. Of 581 rails responding to taped calls, $82.9 \%$ were $<40 \mathrm{~m}$ from the observer, $16.2 \%$ were $40-59 \mathrm{~m}$ from the observer, and $0.9 \%$ were $60 \mathrm{~m}$ from the observer.

Nest searching by dragging ropes or by walking grids was unsuccessful. Few nests were found, and those that were located were done so through accidental discovery, through the use of a dog, or through intensive search of nesting cover from which distraction calls were heard.

Tanner, W. D. 1953. Ecology of the Virginia and King Rails and the Sora in Clay County, Iowa. Ph.D. dissertation. Iowa State College, Ames, Iowa. 154 pages. 
The breeding season phenology, behavior, nest site selection, clutch size, incubation dates, density, development, voice, causes of mortality and food habits of the King Rail, Virginia Rail, and Sora were studied at Dewey’s Pasture Public Shooting Ground, Clay County, from April to September in 1951, April to October in 1952, and in April and May of 1953. The study area was 162.7 ha of prairie interspersed with 28 wetlands. None of the wetlands were $>1.2 \mathrm{~m}$ in depth. The wetlands ranged in size from 0.08 to 7.3 ha.

Counts were conducted every day during spring migration and the prenesting period by walking through each wetland on the study area and recording the number of times Virginia Rails, King Rails, and Soras were seen or flushed. A Labrador retriever accompanied the observer to aid in finding the birds. Each wetland on the study area was systematically walked back and forth in 11-m intervals to search for nests between 22 May and 24 June in 1951 and several days in late May and 17 June to 10 July in 1952. The location of nests was marked with a numbered stake and plotted on a map. The following information was recorded from the nest sites: date and hour of discovery, species, type and relative density of vegetation within 1 yard of the nest, plant species supporting the nest, water depth at the nest, number and condition of eggs, dimension of eggs, nest material, fate of eggs and nest, and the date of hatching or destruction of nest.

Birds were trapped using a modification of a shorebird trap (Low, S. H. 1935. Methods of trapping shore birds. Bird Banding 6:16-22.). Three traps were clover-shaped with three funnel-type entrances. Each of these traps were $0.61 \mathrm{~m}$ high and $0.91 \mathrm{~m}$ in diameter. Woven wire $(3.81 \mathrm{~cm})$ and hardware cloth $(1.27 \mathrm{~cm})$ were used. The fourth trap was rectangular in shape and made of hardware cloth. See Low (1935) for detailed instructions on construction. A collection box (Low 1935) was attached on the floor of each trap and birds entered the box via an inclined ramp. Three or four traps were placed 6.1-7.6 m apart in the marsh and connected by $0.61 \mathrm{~m}$ high woven wire fences extending from the shoreline into the open water near the center of the marsh. Collected birds were taken inside the headquarter's building at the site and weighed to the nearest $0.1 \mathrm{~g}$ in a bag of known weight. Growth stage of each bird was recorded. Each bird was banded with an aluminum U.S. Fish and Wildlife Service band and taken back to the capture site and released.

A total of 124 rail (all species combined) nests were found, and of these, $37.1 \%(n=46)$ were unoccupied. Dominant vegetation around 64.9\% $(n=24)$ of the 37 Virginia Rail nests was hairy sedge, $10.8 \%(n=4)$ were in river bulrush, $10.8 \%(n=4)$ hardstem bulrush, $8.1 \%(n=3)$ cattail, 2.7\% $(n=1)$ bluejoint, and 2.7\% $(n=1)$ sprangletop. Average water depths at 27 nests in 1951 ranged from 15.2 to $45.7 \mathrm{~cm}$ with a mean of 30.7. Average water depths at 8 nests in 1952 ranged from 29.2 to $55.9 \mathrm{~cm}$ with a mean of $37.6 \mathrm{~cm}$.

VanRees-Siewert, K. L. 1993. The influence of wetland age on bird and aquatic macroinvertebrate use of restored Iowa wetlands. M.S. thesis. Iowa State University, Ames, Iowa. 96 pages.

Bird species richness, breeding bird species, and re-vegetation of restored wetlands ranging in age from 1 to 4 yr were studied in northern Iowa from 1991 to 1992. On each wetland, three census stations were established. The first was placed along a random compass bearing and the other two were evenly spaced from this point. The stations were located in the middle of the emergent vegetation zone or at the water's edge if the wetland had no emergent 
vegetation. Birds were censused five times each year between May and June. Counts were made between sunrise and $0900 \mathrm{~h}$ and were not conducted during inclement weather. Waterfowl pairs were counted before the basin was entered. All birds seen or heard during a 6-minute counting period within 20-m radius plots were recorded (Edwards, D. K., G. L. Dorsey, and J. A. Crawford. 1981. A comparison of three avian census methods. Studies in Avian Biology 6:170-176.). Halfway through the counting period, a tape recording of the calls of Sora, Virginia Rail, Least Bittern, and American Bittern were played to elicit responses from these secretive species. The tape included 30 seconds of continuous calls of each species. Birds that were seen or heard outside of the counting interval or point radius were included on a species list. Wetlands were searched for nests weekly in 1991 and bi-weekly in 1992. The author searched the emergent vegetation and $30 \mathrm{~m}$ of the surrounding upland by foot in a zig-zag pattern. The vegetation was scanned for nests or flushing birds. A species was considered breeding if an active nest was found, a brood was seen, or an individual was present in three of five visits.

The vegetation was measured in mid-July using the releve method (Mueller-Dombois, D., and H. Ellenberg. 1974. Aims and methods of vegetation ecology. John Wiley and Sons, Inc. New York, New York. 547 pages.; Galatowitsch, S. M. 1993. Site selection, design criteria and performance assessment for wetland restorations in the prairie pothole region. $\mathrm{PhD}$ dissertation. Iowa State University, Ames, Iowa. 124 pages.). Wetland age, wetland area, percent emergent vegetation cover, and vegetation cover pattern were recorded for each plant species in the wetland. Vegetation cover patterns for each wetland were as follows: 1) <5\% emergent vegetation, marginal band of vegetation $<2 \mathrm{~m}$ in width; 2) centrally located areas of open water surrounded by a band of emergent vegetation $>2 \mathrm{~m}$ in width; 3) centrally located areas of dense emergent vegetation surrounded by a peripheral band of open water; 4) emergent vegetation covering $>95 \%$ of the wetland basin. A detailed cover map of each wetland was drawn and the total percent emergent vegetation was visually estimated.

Aerial photographs were used to measure wetland area, and the history of each wetland was obtained from landowner surveys and the Iowa Department of Natural Resources.

Of 42 bird species detected on restored wetlands, 33\% were waterfowl, 24\% shorebirds, $17 \%$ bitterns and herons, $11 \%$ songbirds, $5 \%$ grebes and coots, $5 \%$ rails, and $5 \%$ were terns. Fifteen species nested in restored wetlands.

Vogel, J. A. 1999. Migration chronology and habitat use of webless migratory game birds in lower Missouri River floodplain wetlands. M.S. thesis. University of Missouri, Columbia, Missouri. 79 pages.

Migration chronology and habitat use of rails, coots, and snipe were studied along the Missouri River floodplain in Missouri during 1996 and 1997. Chronology of use, relative densities, and habitat use of rails, coots, and snipe were studied in remnant wetlands (4 sites), managed moist-soil impoundments (4 sites), connected (4 sites) and non-connected (4 sites) scours, and farmed (5 sites) and unfarmed (4 sites) temporary wetlands. Remnant wetlands were oxbow lakes that were formed when the river changed course and cut off meanders. Moist-soil impoundments were wetland areas impounded by a levee system and where water levels were controlled and where disturbance (plowing, discing, and mowing) was used to enhance the growth of desired moist-soil plant communities. Scours were created during the flood of 1993 when high water levels broke levees adjacent to the river. High pressure and concentrated flows 
through narrow levee breaks created scours on the downstream sides of the levee breaks, which left behind deep (>10 m) scour holes with steep sides, that then leveled off into shallower ( $<50$ $\mathrm{cm})$, more rounded depressions in the stripped zone. Downstream from the stripped zone was the depositional zone where depths of sand deposition ranged from $<15 \mathrm{~cm}$ to $>61 \mathrm{~cm}$.

Connected scours occurred adjacent to the river and water levels fluctuated with the water levels present in the river. Non-connected scours were located in the floodplain where secondary levees had broken and had no direct connection to the river except during flood events. Nonconnected scours had no aquatic or emergent vegetation, although new cottonwood (Populus) and willow (Salix) growth occurred around basin margins. Temporary wetlands were common in the river floodplain because of the undulating topography and were filled with water only in years when precipitation or recent flooding occurred. Farmed temporary wetlands were disturbed by agriculture, whereas unfarmed temporary wetlands were not.

Surveys for webless migratory birds were conducted from early March to mid-May and from mid-August to mid-October, 1996 and 1997, along the lower Missouri River floodplain from northeast of Kansas City, Missouri to just south of Hartsburg, Missouri. Flush counts and visual surveys were conducted from 0600 to $1100 \mathrm{~h}$ on each site every $7 \mathrm{~d}$. Flush counts were used to determine density estimates of King Rail, Sora, Virginia Rail, American Bittern, Least Bittern, and Common Snipe, and were performed along stratified, randomly selected belt transects placed in vegetated shallow $(0-50 \mathrm{~cm})$ water. Belt transects (length not specified) were not permanent and were moved according to water-level fluctuations. Surveys were conducted by four persons in remnant wetlands and moist-soil impoundments because of their large size. Smaller wetland types were surveyed by two persons. Observers, spaced at 5-m intervals, walked through emergent vegetation and flushed rails and bitterns. Number of birds flushed was recorded and the flush site was marked. At flush sites, water depth, vegetation height, plant species, and percent cover of litter and live vegetation (the latter two measured at three levels: basal, $15 \mathrm{~cm}$, and total) were measured using a rectangular sampling frame $(61 \mathrm{~cm}$ by $82 \mathrm{~cm})$. Visual surveys of open water and mudflats were conducted using binoculars to estimate numbers of coots and snipe. Coots and snipe were placed into broad habitat use, behavior, and water depth categories. Habitat categories were dry mud, wet mud, mud/water interface, open water, residual vegetation, robust emergent vegetation (live or dead thick cattail [Typha spp.] or bulrush [Schoenoplectus spp.] stands), other emergent vegetation (perennial knotweed [Polygonum spp.] live or dead, etc.), floating vegetation, flooded shrub-scrub, snag, and artificial structure (dike, pilings, etc.). Behavior categories were feeding, loafing/sleeping, flushed, locomotion (swimming, walking), and flying. Water depth categories were dry mud, wet mud, mud/water interface, foot, foot to tarsus, joint, joint to body, body, and swimming.

Call response surveys were used to determine the relative densities of breeding rails. Rail vocalization recordings were obtained from Cornell Laboratory of Ornithology. In 1996, surveys were conducted in early, mid-, and late May. Surveys began 30 minutes before sunrise and ended $4 \mathrm{~h}$ after sunrise. Calls were played on a portable cassette recorder $0.75 \mathrm{~m}$ above ground and the maximum sound pressure $1 \mathrm{~m}$ from the source was $80 \mathrm{~dB}$. Fifty seconds of male territorial vocalizations of King Rail, Sora, and Virginia Rail were interspersed with 10 seconds of silence. Survey stations were placed every $50 \mathrm{~m}$ along flush count transects. Variables recorded were estimated perpendicular distance $(\mathrm{m})$ to each response, species responding, species call playing at the time of response, habitat type in which the responding bird was located, and environmental data (temperature, wind speed, wind direction, and cloud cover). Species were considered to be breeding if observed on two out of three visits to a site. 
There was no significant difference in numbers of rails detected with call surveys versus flush counts.

Zimmerman, J. L. 1984. Distribution, habitat, and status of the Sora and Virginia Rail in eastern Kansas. Journal of Field Ornithology 55:38-47.

The timing and extent of migration and nesting status of Virginia Rails and Soras were studied at seven sites in eastern Kansas during 1981 and 1982. Herington Marsh was a natural cattail (Typha)-sedge (Carex) marsh. Milford was a small cattail marsh formed in a channel of the Republican River. Eureka Lake was a natural oxbow lake and an associated shallow cattail-knotweed (Polygonum) marsh that was dry during years of low rainfall. River Pond was a small lake with cattail along the margin. Oldsburg Pond was an artificial impoundment; vegetation was primarily composed of knotweeds with cattails in a few areas. Muscotah Marsh was a cattail-bulrush (Scirpus) bog. Marais des Cygnes Marsh had cattail and sedge along the western margin. Rails were censused by use of responses to tape-recorded calls within $3 \mathrm{~h}$ of sunrise and $2 \mathrm{~h}$ of sunset. One rail call was broadcast for 5 minutes, followed by a listening period of 5 minutes. Then the other species call was broadcast for 5 minutes followed by another 5-minute listening period. Census stations were located along the margin of the wetlands, adjacent to suitable rail habitat. Stations were at least $100 \mathrm{~m}$ apart. Censuses were conducted from the third week in March until the fourth week of June. Audio tapes were obtained from the Library of Natural Sounds, Laboratory of Ornithology, Cornell University, Ithaca, New York. Habitat characteristics were recorded along transects at survey stations where rails responded to taped calls and at all other stations at that study site. Transects were directed either toward the direction of the responding rail or, if no rails responded, toward the direction in which the speakers were pointed. Data were collected at four points along the transect. The four points were determined by pacing, and the number of paces were selected based on a table of random numbers. Percent cover of plant species versus water was estimated in a 1-m radius circle and water depths and vegetation height above water were measured at each point along the transect. Vegetation height was determined by measuring vegetation above water level at 10 randomly selected points $1 \mathrm{~m}$ from the sampling point and calculating a mean. Values from the four points along each transect were used to generate average measurements for each survey station.

Mean water depth at sites where Virginia Rails were detected was $9.9 \mathrm{~cm}(\mathrm{n}=14)$. Mean water depths along transects at 43 sites where rails (Sora and Virginia Rails combined) were detected ranged from 7 to $27.7 \mathrm{~cm}$. Mean vegetation height at 43 sites where rails were present ranged from 56.9 to $109.8 \mathrm{~cm}$. Mean percent open water at 43 sites where both rails were present ranged from 9.8 to $33.9 \%$.

The following sources may provide more information on methods.

Bishop, R. A., and R. Barratt. 1969. Capturing waterfowl in Iowa by night-lighting. Journal of Wildlife Management 33:956-960.

Conway, C. J. 2002. Standardized North American marsh bird monitoring protocols. 
U.S. Geological Survey, Arizona Cooperative Fish and Wildlife Research Unit, University of Arizona, Tucson, Arizona. 17 pages.

Fuertes, B., J. Garcia, and J. M. Colino. 2002. Use of fish nets as a method to capture small rails. Journal of Field Ornithology 73:220-223.

Gibbs, J. P., and S. M. Melvin. 1997. Power to detect trends in waterbird abundance with callresponse surveys. Journal of Wildlife Management 61:1262-1267.

Haramis, M., and G. D. Kearns. 1999. Sora Rail studies on the Patuxent River, Maryland. Pages 37 in Proceedings of the marsh bird monitoring workshop. U.S. Fish and Wildlife Service, Denver, Colorado.

Johnson, R. R., B. T. Brown, L. T. Haight, and J. M. Simpson. 1981. Playback recordings as a special avian censusing technique. Studies in Avian Biology 6:68-75.

Kearns, G. D., N. B. Kwartin, D. F. Brinker, and G. M. Haramis. 1998. Digital playback and improved trap design enhances capture of migrant Soras and Virginia Rails. Journal of Field Ornithology 69:466-473.

Marion, W. R., T. E. O’Meara, and D. S. Maehr. 1981. Use of playback recordings in sampling elusive or secretive birds. Studies in Avian Biology 6:81-85.

Norton, M. R., B. A. Gingras, and A. J. Puchniak . 2003. Marshbird, shorebird, and songbird use of small wetlands in Alberta. Unpublished report, Canadian Wildlife Service, Environment Canada, Edmonton, Alberta. 72 pages.

Skirvin, A. A. 1981. Effect of time of day and time of season on the number of observations and density estimates of breeding birds. Studies in Avian Biology 6:271-274.

Skoloda, J., and C. A. Ribic. 1999. Density indices for Sora and Virginia Rails. Pages 45-46 in Proceedings of the marsh bird monitoring workshop. U.S. Fish and Wildlife Service, Denver, Colorado. 